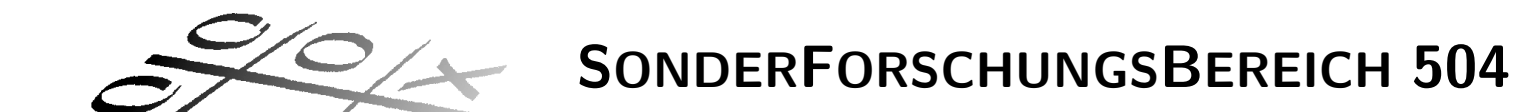

Rationalitätskonzepte,

Entscheidungsverhalten und

ökonomische Modellierung

\begin{tabular}{c} 
No. 07-28 \\
GLOBAL AGING - Issues, Answers, More \\
Questions \\
Axel Börsch-Supan* \\
\hline
\end{tabular}

June 2004

Financial support from the Deutsche Forschungsgemeinschaft, SFB 504, at the University of Mannheim, is gratefully acknowledged.

*Sonderforschungsbereich 504, email: boersch-supan@mea.uni-mannheim.de

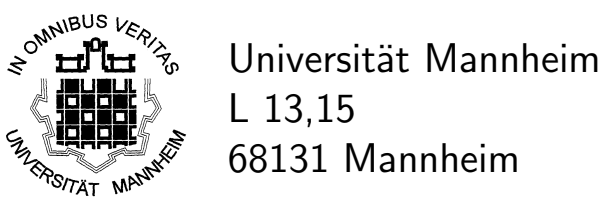




\title{
GLOBAL AGING ISSUES, ANSWERS, MORE QUESTIONS
}

\author{
Axel Börsch-Supan \\ Mannheim Research Institute for the Economics of Aging (MEA), University of Mannheim, Germany \\ National Bureau of Economic Research (NBER), Cambridge, Massachusetts \\ Paper Commissioned by the Michigan Retirement Research Center (MRRC)
}

\begin{abstract}
Global aging will be a major determinant of long run economic development in industrial and developing countries. The extent of the demographic changes is dramatic and will deeply affect future labor, financial and goods markets. The expected strain on public budgets and especially social security has already received prominent attention, but the aging poses many other economic challenges that threaten productivity and growth if they remain unaddressed.

While aging is global there are marked differences in the speed and the extent of the aging processes across countries. These differences are likely to generate different growth paths and change the international pecking order, e.g. within the G8 countries. Due to the globalization of labor, financial and goods markets, however, these differential demographic developments will also precipitate trade and factor movements. Exploiting these movements offers large chances during the aging process.

Purpose of this paper is to review the most important economic chances and challenges due to global aging. It summarizes what we know and identifies research areas where it is important to know more.
\end{abstract}

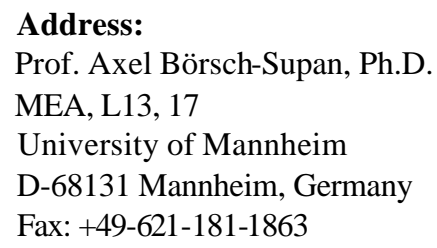

ACKNOWLEDGEMENTS: I would like to thank Andrew Abel, Moritz Kraemer, Marilyn Moon and the participants of the "Workshop on Global Aging" for their helpful comments. MRRC commissioned this paper. We are grateful to the Social Security Administration's Office of Policy for financial support. Additional financial support came from the Deutsche Forschungsgemeinschaft, the VW-Stiftung, the Gesamtverband der Deutschen Versicherungswirtschaft and the Land Baden Württemberg. 


\section{TABLE OF CONTENTS}

\section{Introduction}

\section{Demographics}

2.1 Deterministic and stochastic projections: How reliable are they?

2.2 Economic incentives to fertility and migration: Do we understand causality?

\section{Labor Markets}

3.1 Labor supply: Which countries will face declining labor supply? What does it mean for GDP?

3.2 Labor productivity: Will labor productivity decline in aging countries? By how much? How to cope with an aging work force?

3.3 Interactions between labor and product markets: How will changing product demand shift sectoral labor demand?

3.4 Interactions between labor and capital markets: How sensitively will retirement age react to economic fluctuations, in particular stock market performance, with feedbacks to consumption and saving?

\section{Interactions between Labor, Product and Capital Markets}

4.1 Interactions between labor and product markets: How will changing product demand shift sectoral labor demand?

4.2 Interactions between labor and capital markets: How sensitively will retirement age react to economic fluctuations, in particular stock market performance, with feedbacks to consumption and saving?

\section{Capital Markets}

5.1 Supply of savings: Does an elderly economy save less? Feedback from pension reform?

5.2 Asset meltdown: Will rate of return and property values decline in the 2030s? Does globalization help or hurt?

5.3 Portfolio choice: Does aging impact differentially the return on stocks, bonds, real estate? How will portfolio choice respond?

5.4 International capital flows: How large are aging induced international capital flows? From where to where do they go? How much are they dictated by capital market restrictions and home bias?

5.5 Corporate Governance: Will pension reform foster US -style capital markets in Europe? Feedback to capital productivity and rates of return?

\section{Summary and Conclusions}




\section{GLOBAL AGING: ISSUES, ANSWERS, MORE QUESTIONS by Axel H. Börsch-Supan}

\section{Introduction}

The expected change in the age structure in virtually all industrialized countries - but also in many developing countries - is dramatic and will lead to a substantially higher proportion of older people in the world. The aging process deeply affects future labor, financial and commodity markets. On a macroeconomic level, labor is becoming relatively scarce in the aging countries while capital becomes relatively more abundant. This precipitates changes in the relative price of labor, will lead to higher capital intensity, and might generate large international flows of labor, capital and goods from the faster to the slower aging countries. On a microeconomic level, the age composition of the labor force will change which might affect labor productivity. Consumption and savings patterns are likely to alter when the elderly become a larger proportion of consumers and savers, with widespread implications for capital and goods markets.

While aging is global, there are marked international differences in the speed and the extent of the aging processes. Even within the industrialized countries, differences are large. Europe and Japan have already a much older population than North-America. Italy and Germany are aging faster than France and Great Britain. In Asia, some countries start from a relatively young population, but aging is very quick. A particular dramatic example is China. Due to the globalization of our economies, no study of aging can disregard these differential changes. International flows of capital, goods and services, and labor - in descending order of mobility - will be important mechanisms moderating the effects of population aging in each individual country.

A central question for economists and politicians alike is how demographic change will affect the wealth of nations. Which countries will gain, which countries will loose in the international pecking order? Equally important is the question how these gains and losses can be influenced by public policy. With these two core questions in mind, this paper reviews the most important economic challenges and 
chances due to global aging, summarizes what we know, and identifies research areas where it is important to know more.

One way to think about the effects of aging on the wealth of nations is to start from the fundamental components that determine a nation's output and income. Let national output $Y$ (GDP) of a country with $N$ inhabitants be

$$
Y=A \cdot F(L, K) \text {. }
$$

From a macroeconomic point of view, the main effect of aging is to reduce the relative size of the labor force $\mathrm{L}$ as a share of total population $N$. In some countries, the labor force $L$ will even decline in absolute size. Unless this is compensated by an increase in total factor productivity $A$ and/or an increase in the capital stock $K$, their national output will decline. Since $L$ is changing quite differently across countries, the growth of $Y$ will reflect these differences. Hence, the current list of G8 countries might look quite different in one or two generations from now.

Absolute size may not be the most relevant yardstick. Smaller countries, however, do not need to be unhappier or poorer countries. From a more individualistic point of view, per capital output is

$$
Y / N=A \cdot G(L / N, K / L) .
$$

Per capita output $Y / N$ may stay constant or even increase, in spite of a shrinking population $N$ (and a decreasing total output $Y$ along with it) if labor force participation $L / N$ and capital intensity $K / L$ increase. This is one source of chances from the aging process.

Finally, not all income needs to come from domestic production. In addition to wages and capital income from domestic production, equivalent to $Y$, foreign direct investment may create capital income from foreign production. GNP may become substantially larger than GDP if foreign direct investment creates large returns. Here are major chances during the global aging process.

This paper is structured according to these sources of output and income changes precipitated by the aging process. The paper takes largely a macroeconomic view. It does not deal in any narrow sense with the central issue of reforming the pension, health and long-term care insurance systems - however, pension and health care reforms may have important macroeconomic implications, and we will discuss 
them where appropriate. In addition, some central macroeconomic issues, such as the productivity of an aging work force, require a distinct microeconomic view to be understood, and we will take our time to take this view.

The paper is structured as follows. Section 2 briefly depicts the central demographic facts and discusses open research issues relevant for the economic analysis. Section 3 looks at labor markets: What do we know about labor supply, labor productivity and labor mobility? Where do we need more research on labor market effects of population aging? Section 4 discusses the interactions between labor, market and capital markets. Consumer demand will be deeply affected by aging since an elderly population has very different consumption patterns. This induces sectoral hbor demand shifts possibly accompanied by higher frictional unemployment. With the increasing importance of private pensions, capital markets and product markets may become more closely linked than they are currently. Section 5 is devoted to capital market issues. Will world capital markets face a shortage of loanable funds when baby boomers retire and withdraw their savings? How much new savings will pension reforms generate? Which capital market issues, such as corporate governance and capital productivity, require more research efforts? Section 6 summarizes and concludes.

The paper discusses these issues in generality, then proceeds with concrete examples of one aging country, namely Germany. There are several reasons to study Germany as a particularly interesting example for a country in the midst of global aging. Together with Italy and Japan, Germany is ahead of the United States in terms of aging. Germany's old-age dependency ratio in 2003 corresponds to that of the United States in about 2023, twenty years later. Germany has a very globalized economy, with a high trade volume, large foreign direct investments, and the highest per capital immigration rate of the EU. Finally, Germany does not only have an old population, it also has an old economic system, with labor, capital market and social policy institutions created in the 1950s and now under substantial pressure. Germany is an ideal show case for the challenges - and chances! - of global aging for a highly developed economy. 


\section{Demographics}

At mid-2000, world population stood at 6.1 billion. While the world population has constantly grown, its annual growth rate has decreased from 2.04\% during the period from 1965 to 1970 to $1.2 \%$ annually now. It is expected that this decrease in world population growth will continue. In the medium variant of the United Nations' current world population projections, the growth rate is projected to decrease to $0.5 \%$ by 2050 . By then, world population will have increased to 9.3 billion. Most of this increase in the size of the world population takes place in less developed regions (United Nations, 2001).

Throughout the world, demographic processes are determined by the so-called demographic transition which is characterized by falling mortality rates followed by a decline in birth rates, resulting in population aging and thereby reducing the population growth rate or turning it to negative. While the patterns of population aging are similar in most countries, the timing differs substantially. Europe and some Asian countries have almost passed the closing stages of the demographic transition process while Latin America is only at the beginning stages (Bloom and Williamson, 1998). So far, characteristics of a demographic transition process cannot be identified in Africa - fertility is at the highest level worldwide, and even though child mortality is declining, Ife expectancy is still very low - in part due to the enormous impact of AIDS (United Nations, 2001).

The extent of global aging is most visible in the population pyramid, see Figure 1. In 1990, world population essentially was a pyramid. In 2050, it will have the shape of a bell, and then - according to the UN - more or less stabilize. Between 2000 and 2050, world population will add especially persons aged between 40 and 65 as can be seen by the darkly shaded area in figure 1 .

\section{Figure 1: World Population Pyramid}




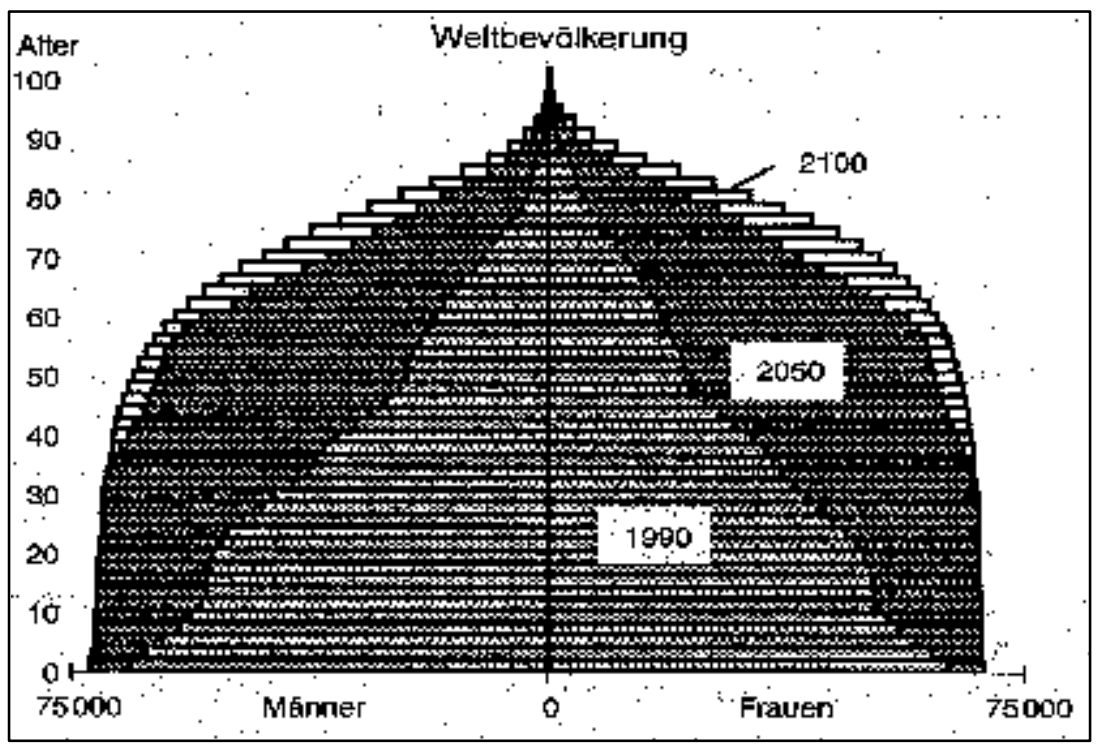

Source: United Nations (2001).

There are marked differences in the extent and timing of the aging process even within the developed countries, see Figure 2. Japan and Germany have the highest old-age dependency rations, followed by the EU14, an average of all EU-countries (as of the year 2000) except Germany. The United States is considerably younger than the EU, and the remaining industrial countries (except EU, USA and Japan) are even younger. Section 5 of this paper will show that these international differences within the OECD will create the largest international capital movements in the medium run, not movements between the industrialized and the developing world, simply because the GDP of the industrialized countries is so much larger. In the long run, the Chinese and Indian economies may change this pattern considerably. 


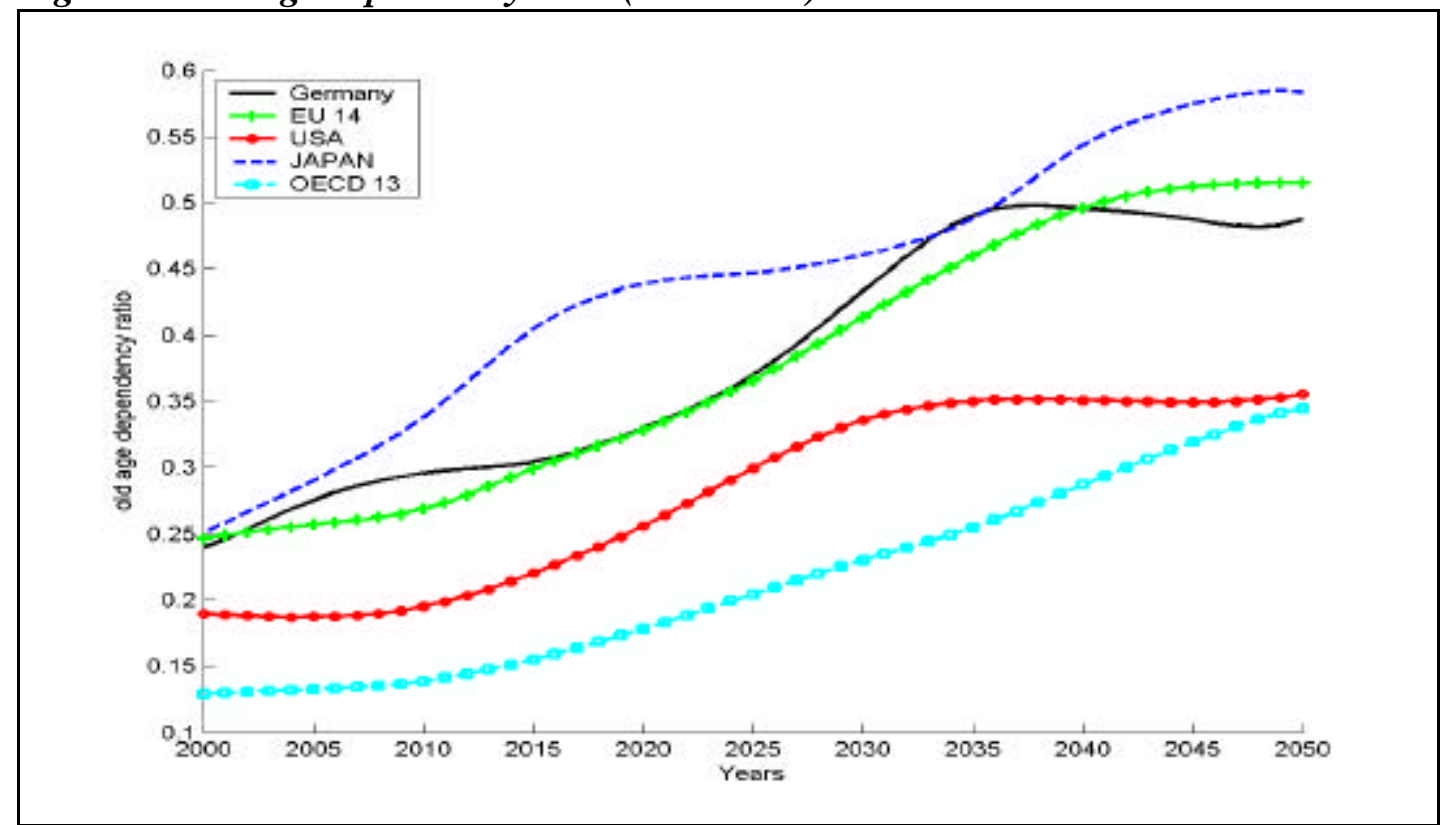

Source: United Nations (2001).

\subsection{Stochastic population forecasts}

This paper concerns open issues in the economics, not the demographics of global aging. Nevertheless, since the economics of global aging fundamentally depend on demographic forecasts, it is useful to point out the most important research issues here. Note that the reliability of demographic projections is not only an issue of getting economic forecasts right, it also has direct economic implications. International capital movements are precipitated by expectations which in turn are formed with a significant influence of population projections. Today's foreign direct investment decisions are therefore influenced by what demographers project for the future as evidenced by Higgins (1998), Eichengreen and Fifer (2002), and Lührmann (2002).

Compared to economic projections, medium run demographic projections (one generation ahead) are reasonably precise because most of the population one generation ahead is already alive. Formidable challenges, however, are longer run projections and a satisfactory description of the uncertainty involved in these projections. Stochastic projection methods (see Lee 1993, 1998, Lee and Tuljapurkar, 1994) 
offer a verifiable mechanism to generate error bands. Their Achilles heel, however, is the weak statistical foundation of the underlying stochastic processes, to a great extent due to the lack of readily available historical data. Further research is needed to construct long time series of mortality, fertility and migration.

\subsection{Endogenous demography}

On a deeper level, research on the feedback mechanisms and the causality of demographic changes and the international differences in demographic processes has not come far. We do not really understand why Italy has a lower fertility rate than France, and why the German fertility rate has stayed amazingly constant since the mid-1970s while all candidate variables that are commonly employed to explain fertility have changed. The link between the social security system and fertility (Cigno, 1995) remains controversial. This is highly policy-relevant, since particularly in low-fertility countries such as Italy and Germany pension reform proposals circulate which argue in favor of a link between pension benefits and children born (Sinn, 1997). Of equal importance and not fully understood is the link between female labor force participation and fertility. The cross-national correlation between female LFP and fertility has changed sign some 10 years ago, from negative to positive, without a satisfying explanation so far (Hank and Kreyenfeld, 2003), ridiculing scientists who called such correlations "laws" in the 1970s and based public policy on it.

The largest wild card in demographic projections is migration. The German statistical office has predicted a decline in the German population in each projection since the early 1980s. It has never occurred because migration was always larger than predicted. While we have many theoretical models describing the link between economic circumstances and migration, we do not have quantitative models that are able to predict how global aging will effect migration. Since capital moves with considerably less frictions than labor, we are better able to predict international capital than labor movements. Both, however, may interact, and both are important moderators of the economic impacts of global aging. The link between economics and demography is complex, long-run, and still an under-researched area, in spite of its importance for economic development and social security perspectives. 


\section{Labor markets}

Understanding the development of the labor force during the next decades is crucial for any analysis of global aging because the long run macroeconomic development is dominated by fundamentals such as the relative scarcity of labor and the relative abundance of capital. The essential macroeconomic effects of population aging are a changing balance between capital and labor, and between labor supply and demand for consumption. An aging society has relatively few workers for the existing capital stock that produces consumption goods for a still relatively large number of consumers. ${ }^{1}$ These changing fundamentals do not only affect each country in isolation but also the relation among countries. ${ }^{2}$

This section focuses primarily on the isolated impact of population aging on labor markets and asks to what extent public policy may be able to mitigate potential problems. It sheds light on the structural changes occurring on the labor market - the age structure of workers, their labor productivity and wage structure. In passim, we also look at interactions between labor and product, and between labor and capital markets. Section 5 examines the implications of population aging on capital markets. We postpone a general equilibrium analysis of growth until then. This section may therefore be regarded as a partial analysis dealing with human capital, while the complementary section 5 deals with real capital and the general equilibrium of an aging economy in a globalized world.

\subsection{Labor supply}

Predictions of labor supply have two components: a demographic projection (working age population) plus assumptions on labor force participation rates specific to age, gender, etc. Labor force participation rates are policy related; for example, they heavily depend on the rules determining labor market entry (through the education system, see Skirbekk, 2004a) and retirement (through statutory retirement age and actuarial adjustments, see Gruber and Wise, 1999).

\footnotetext{
${ }^{1}$ Some countries have been projected to shrink in absolute size, Germa ny among others. Under realistic estimates of migration, however, this shrinkage will be very small until the baby boom generation deceases.

${ }^{2}$ Bryant, Faruqee and Lelculescu (2001).
} 
Most developed countries have produced projections of labor supply, but there is no good compilation of them, and even less information on the exact assumptions, including the underlying projections of pension rules. Projections of the impact of global aging on the wealth of nations are therefore usually based on relatively coarse projections of labor supply (Attanasio and Violante 2000; Börsch-Supan, Ludwig and Winter 2002, 2004; INGENUE 2001). A more systematic approach to this fundamental input would be an important preliminary step for more reliable analyses of global aging.

Actual employment of course also depends on labor demand. While most economists believe that in the long run employment is determined by supply, the long-lasting unemployment in Europe with its potential structural reasons may affect actual employment also in the future. Labor market rigidities affect the implications of global aging in several ways. As we will see in subsection 4.1, aging changes the structure of consumption demand, therefore also the sectoral demand for labor. If the Continental European economies keep failing to permit quicker adjustments to changed circumstances, employment will fall quicker than labor supply due to unemployment in those sectors that are shrinking, and a lack of available new jobs in the potentially growing sectors. Migration is also heavily influenced by labor market regulations. Unemployment policies which fail to create jobs for less qualified persons may exacerbate the duality of labor markets in Europe: on the one hand, a rising excess demand for qualified labor is likely to emerge when cohorts become smaller during the aging process; on the other hand, unemployment among the less-qualified persons remains constant because the root cause for such unemployment (the large wedge between marginal productivity and total labor compensation) has not been removed. Since the economic essence of aging is a lack of labor relative to existing capital and population, under usage of labor even at low qualification levels amplifies the negative effects of population aging.

Figure 3a depicts aggregate employment rates based on OECD (2002) and Börsch-Supan, Ludwig and Winter (2002). Level and shapes differ dramatically. They lead to "economic dependency ratios" (the number of pensioners as a percentage of the number of workers, see figure $3 b$ which are much higher in Europe than in the United States. This economic dependency ratio is the core statistic to judge the economic effects of global aging. According to these projections, the United States will never reach that level of economic dependency which Germany is already suffering fromright now. 


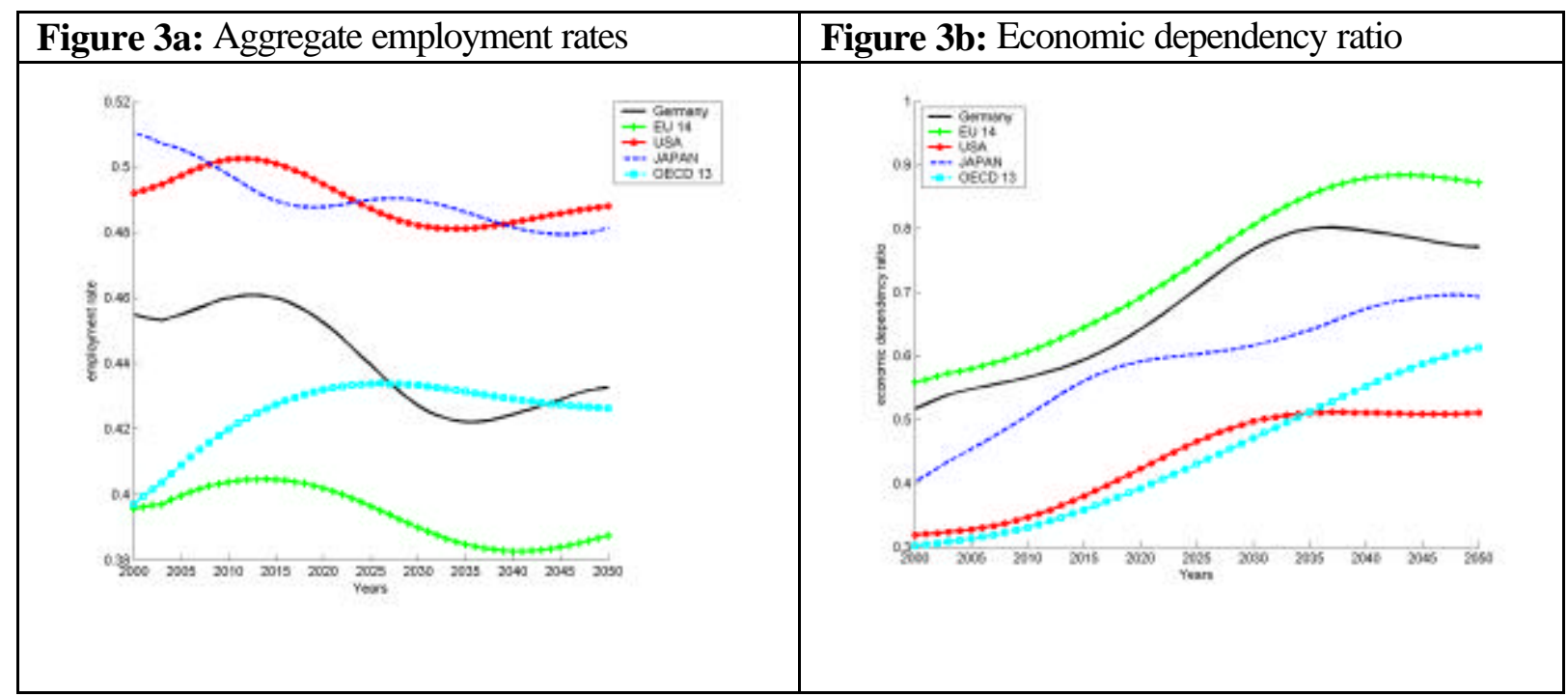

Source: Börsch-Supan, Ludwig and Winter 2002.

Figure 3 shows the leverage of employment on the economic implications of aging. Comparing this figure with the purely demography-based figure 2 shows that the higher labor force particip ation in Japan makes this country less vulnerable to aging than Europe. By the same token, policies affecting employment, such as earlier labor market entry ages due to education reform and later labor market exit ages due to pension reform are crucial ingredients to minimize the economic effects of population aging. Any differential success in implementing such policies will have straightforward implications on global aging and the relative position of countries in the international pecking order.

The strictly falling employment ratio in Germany during the 25 years between 2010 and 2035 (Figure 3a) actually translates in a dramatically shrinking labor force. Figure 4 shows the magnitude of this decline under three scenarios. Details are given in Börsch-Supan (2003b); in essence, the very optimistic scenario E3 (upper graph) assumes large increases in retirement age and female labor force participation plus an almost complete reduction of unemployment, while the lower graph E1 assumes no change in age and gender-specific employment rates at all. The Scenario E2 represents the - in our view - most realistic set of assumptions in between. Despite the increase in participation rates predicted by the most probable scenario E2, the size of the labor force as measured in the year 2000 is nonetheless set to fall by 
around 8 million in the long term. In other words, the labor market will contract - in absolute terms by more than twice the current number of unemployed.

It is very unlikely that this decline can be compensated by an equiproportional increase in productivity and/or capital accumulation, as we will show below. Total German GDP will therefore almost surely decline, and Germany is likely to become member with a declining weight among the G8 countries.

Figure 4: Labor force in Germany, 2000-2050 [in millions]

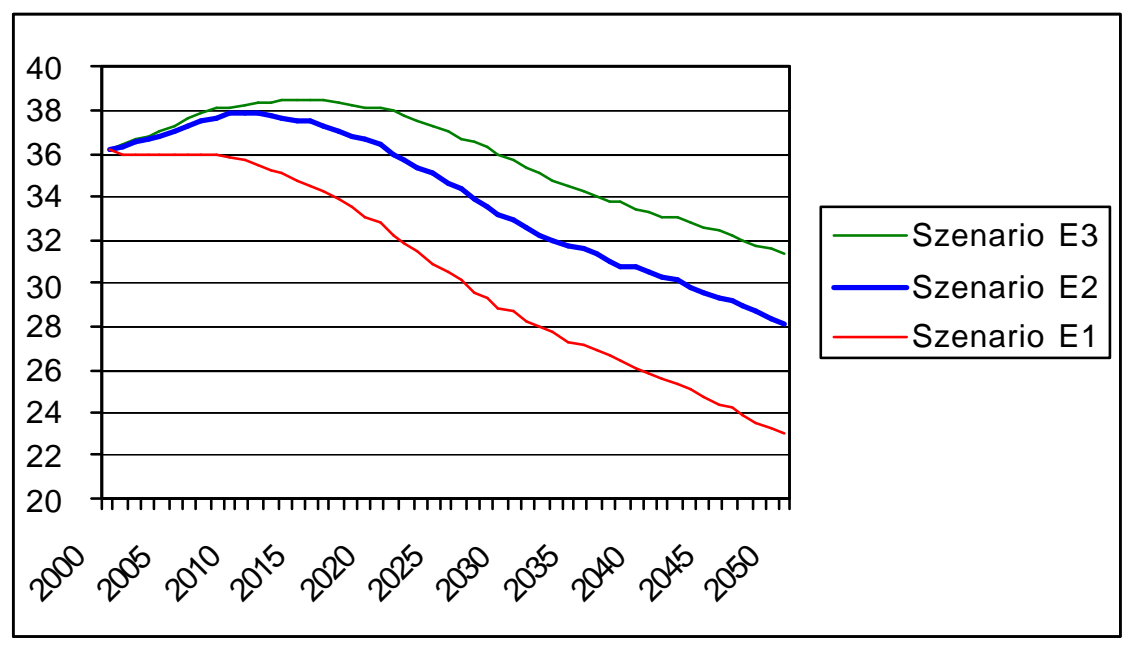

Source: Börsch-Supan 2003.

From a domestic consumer's point of view, total GDP might be less relevant than GDP per capita. Since the German total population is also likely to decline, labor force as a share of the adult population - the so called support ratio - will decline slower than total labor force. Nevertheless, in the middle scenario E2, the support ratio drops from $56 \%$ in the year 2000 to $49 \%$ in the year 2035 , a $15 \%$-decline in 25 years, see Figure 5. 
Figure 5: Support ratio (labor force as share of total adult population), 2000-2050 [in \%]

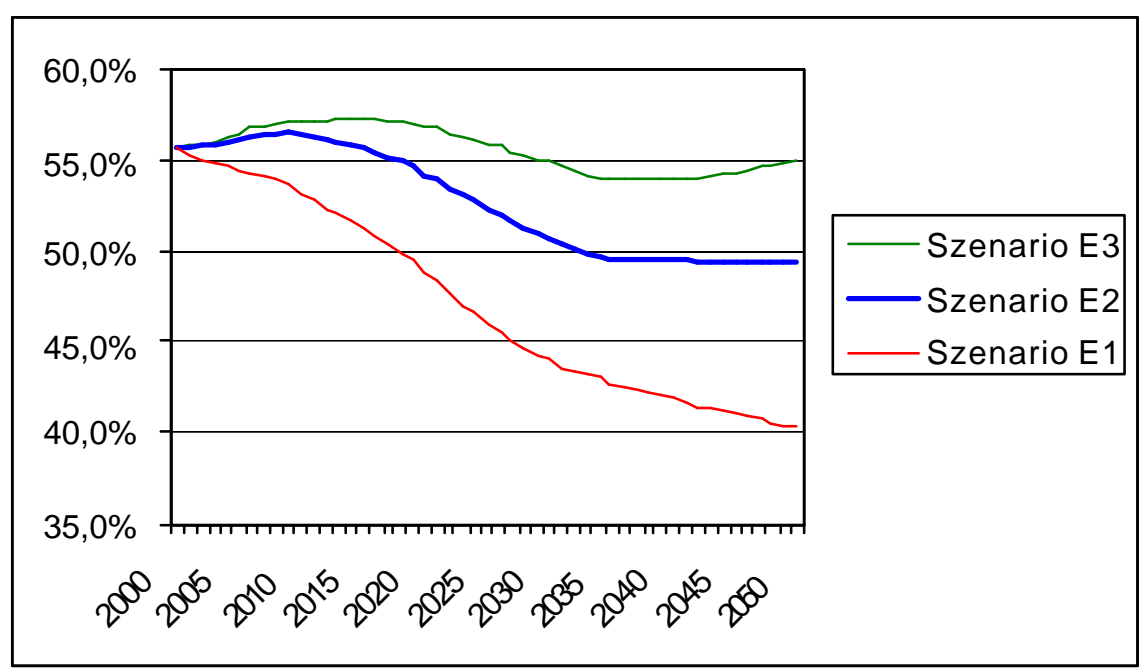

Source: Börsch-Supan 2003.

Figure 5 is useful because it demonstrates the force of aging in an understandable metric. A decline of $15 \%$ in the 25 year period between 2010 and 2035 translates in a negative growth rate of around 0.45 percentage points per annum from 2010 to 2035. The long-term real productivity growth of the German economy (1871-1995) has been estimated to be approximately 1.6\% (Buchheim 1998). In other words, the negative economic force of aging, simply by reducing the number of workers available to produce goods and services, corresponds to between a quarter and a third of the average annual productivity growth. To compensate for the lack of workers by higher productivity of the existing workers, total factor productivity would need increase by $40 \%$, probably an unrealistic figure.

Figure 5 also shows the variability range for this forecast. In the most pessimistic scenario E3, the impact of the declining support ratio is huge. On the other hand, in the optimistic scenario E1 the shift in the age structure is compensated for almost entirely by the increase in participation rates.

This example bears several lessons for future studies on global aging. First, the huge variability of the projections and the leverage of employment on GDP make clear, that it is important to better understand how public policy can influence labor force participation rates. Structural reforms such as education reform and pension reform have potentially huge "side-effects" on GDP growth through their impact on employment, over and above the often more prominently discussed impacts on social budgets. While 
already much research has been devoted to the impact of pension rules on retirement age (BörschSupan and Schnabel, 1998; Gruber and Wise, 1999; Börsch-Supan, 2000b), we lack reliable and strictly comparable cross-national micro data to reduce the large variability of these estimated impacts. There is also little research on the other channels through which social policy affects employment in all age ranges, including labor force entry.

Second, the above example shows how strongly the differential force of global aging depends on to what extent an increasing quality of labor will compensate for the decreasing quantity of labor. "Side effects" of structural reforms on productivity may in the long-run dominate any direct but static effects, because they change the growth path of the economy. We will come back to this point in the following subsection, which discusses labor productivity, and in subsection 5.5, which discusses capital productivity.

While the above examples yield helpfuldemonstrations of the force of aging, the actual impact of aging on GDP can only be assessed in general equilibrium, since capital accumulation may change during the aging process as well. Projections thus require general equilibrium models which are sufficiently realistic to model demography, capital accumulation and employment. We will introduce such models in Section 5 , since they are of particular importance in predicting capital market effects.

As a quick preview, figure 6 shows predicted GDP per capita in Germany, net of an exogenous productivity growth of $1.5 \%$ per annum, based on a OLG-model developed by Börsch-Supan, Ludwig and Winter (2002), described in Section 5. Netting the exogenous growth rate out is helpful in order to isolate the two other forces of growth: capital accumulation and labor force decline. Figure 6 shows that capital accumulation will increase GDP per capita until about 2015. Thereafter, the decline of employment overcompensates the growth effect of capital accumulation, and GDP per capita begins to decline relative to the path without aging. 
Figure 6: Predicted GDP per capita, net of exogenous GDP growth

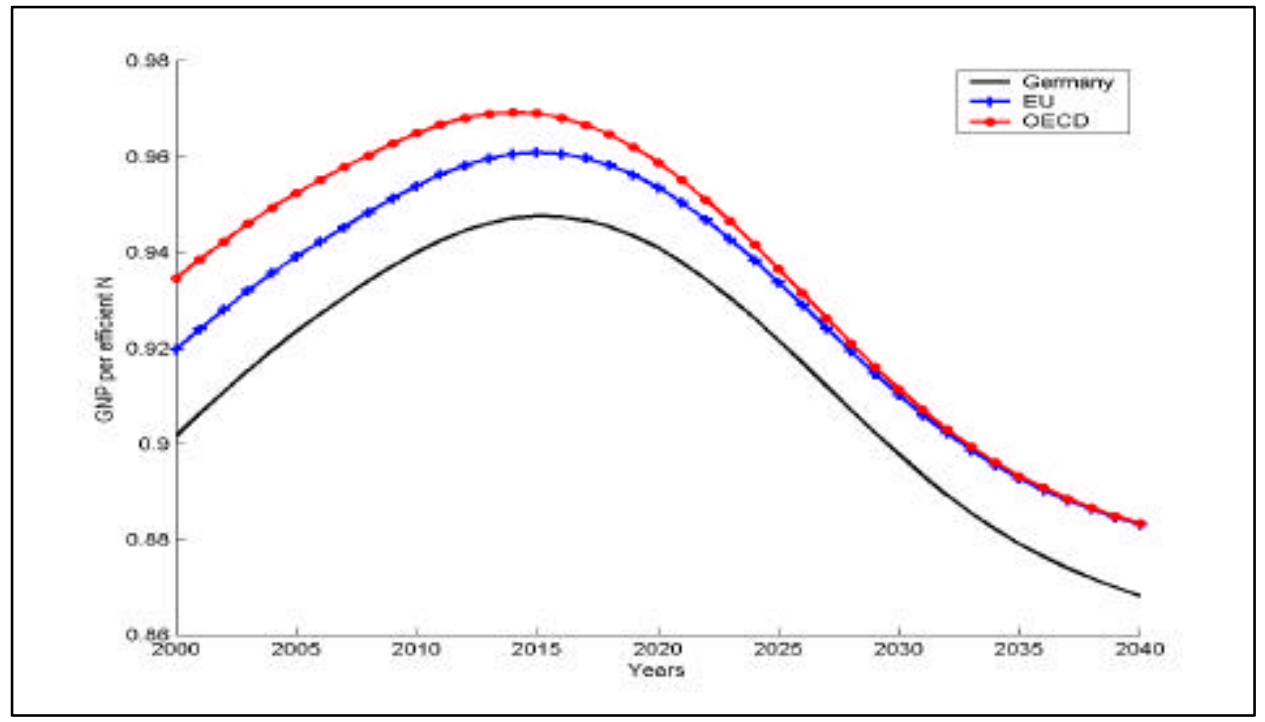

Source: Own calculations based on Börsch-Supan, Ludwig and Winter (2002)

\subsection{Labor productivity}

Not only the size but also the age structure of the working population will change radically in the coming decades. We again use Germany as an example for the how dramatic the change will be. Figure 7 shows the age composition of the labor force between the years 2000 and 2050. The peak of this age distribution very clearly moves from left to right. The modal age in the year 2000 is at age $36 ; 10$ years later the peak age increases to 46 years; and a further 10 years on it has risen to 54 years. The baby boomers then retire - the age distribution curve flattens out and changes very little in the following decades. 
Figure 7: Age structure of the working population, 2000-2050
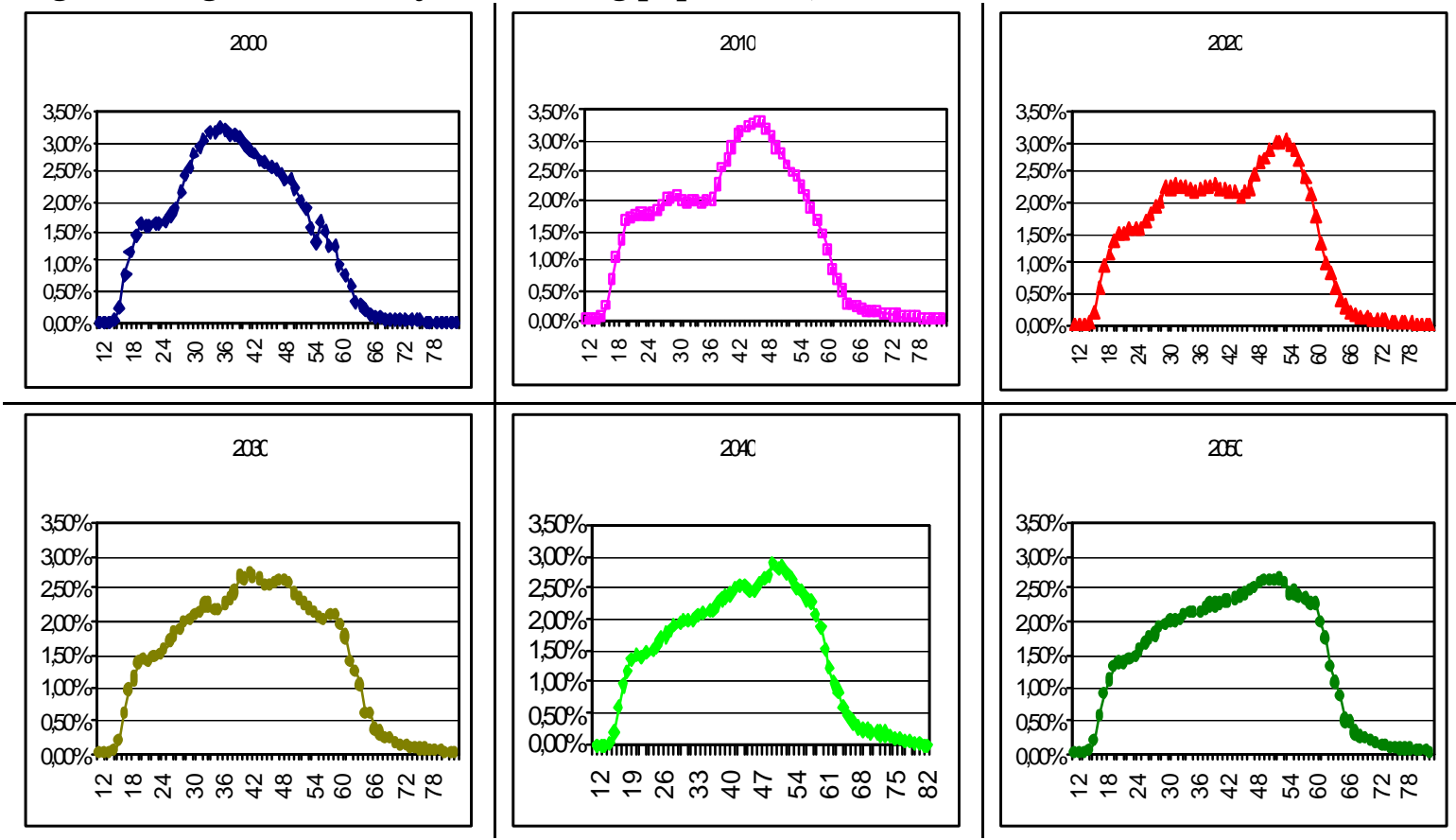

Source: Börsch-Supan 2003.

Correspondingly, the average age of the labor force will increase from 29 to 42.5 years in the next 20 years, will then stagnate for 15 years and subsequently increase by one further year (Figure 8a). The dramatic change in the age structure is particularly exemplified by the share of workers aged 55 years or older in the labor force (Figure 8b). An interesting phenomenon is the temporary "rejuvenation" of the labor force after the numerous baby boomers have retired. The figure, however, also reveals - and this is an important message - that the shift in the age structure is not a transitory phenomenon which subsides after the baby boom generation has deceased. 
Figure 8a: Average age of the labor force

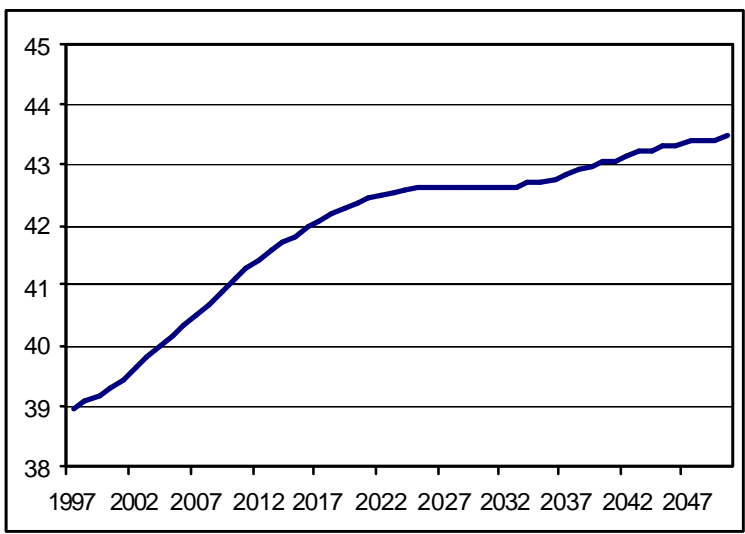

Source:Börsch-Supan 2003.
Figure 8b:

Share of the labor force over 55 years

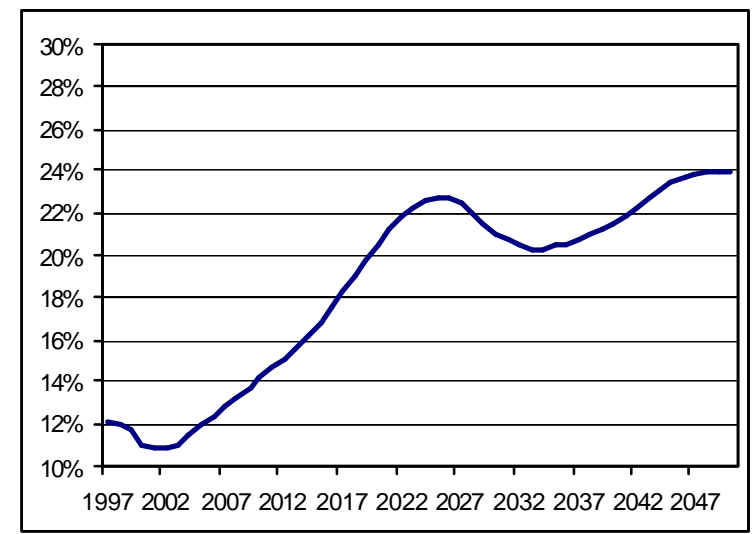

This fundamental change in the age structure of the working population will have profound effects on the microeconomics and the sociology of the labor market. The most important - and most controversial aspect is the potential effect on labor productivity. If labor productivity is age dependent, a shift in the age structure will also bring about a change in aggregate productivity, even if age-specific productivity were to remain constant. This section provides a rough estimate of this effect's approximate magnitude. This is not a simple task because there is no reliable data available on age-specific labor productivity. Barth et al. (1993) conclude from a survey of human resource executives in 406 organizations that "Older workers were consistently rated as having more positive attitudes, being more reliable, and possessing better skills than the average worker; they were rated worse than the average worker when it comes to health care costs, flexibility in accepting new assignments, and suitability for training." Measuring these countervailing forces is difficult. Moreover, workers select themselves in sectors and profe ssions according to their own productivity and this self-selection changes with age - and consequently with the shift in the age structure. Age-specific labor productivity must therefore be identified from panel data on work input and attributable output. Studies based on cross-sectional data confound age, cohort and selection effects. 
Skirbekk (2004b) and Börsch-Supan, Düzgün and Weiss (2004) provide recent reviews over the existing literature, distinguishing among three kinds of studies: studies measuring cognitive abilities; studies using supervisors' evaluations, and econometric studies using firm data. All three approaches have severe drawbacks: Using cognitive abilities as yardstick ignores experience and managerial abilities which may increase with age rather than decrease; supervisors' evaluations may reflect common prejudices rather than objective abilities, they may also be dominated by labor relations aspects; econometric studies using firm data exhibit little variation in average employee's age and suffer from confounding factors. ${ }^{3}$ Börsch-Supan, Düzgün and Weiss (2004) report on a study design based on the performance of welldefined working groups in two large German manufacturing companies; no results are yet available. Such studies are expensive but may overcome the above-mentioned difficulties. Understanding productivity of older workers and how to influence it is a major underresearched area of importance to understand future economic growth.

The importance of these issues is underlined by applying two extreme estimates of age-specific productivity derived from Kotlikoff and Wise (1989) to the German data which should, roughly at least, capture the range of possible effects. Kotlikoff and Wise (1989) evaluated confidential data originating from a major US American service enterprise. They provide two estimates. The first estimate uses age and seniority-specific earnings of sales staff, which are proportionally linked to the value of the sales contracts clinched by such staff, and interprets them as age and seniority-specific productivity. Figure 9 shows these earnings as a function of age (abscissa) and age on joining the firm (set of curves parameter).

\footnotetext{
${ }^{3}$ See Hutchins (2001) for a discussion of the usefulness of employer survey to address these is sues.
} 
Figure 9: Age and seniority-specific earnings of salesmen

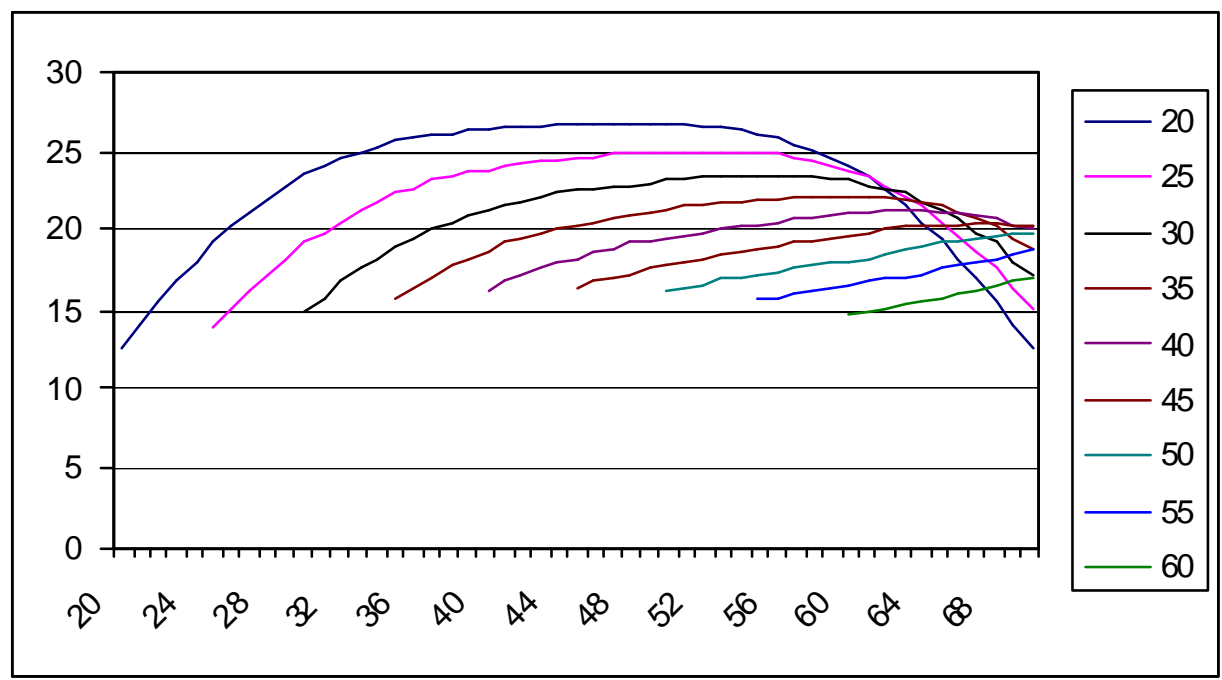

Source: Kotlikoff and Wise (1989)

Since the curves are basically congruent, we draw on the profile of sales employees recruited at the age of 20 for the first estimate of age-specific labor productivity. This curve is relatively flat. The employee's piece rate remuneration more than doubles during the first junior employment period of around 15 years. Piece-rate remuneration - our initial measure of productivity - only begins to fall again between the ages of 55 and 60 years.

Because salesmen, whose pay is wholly performance related are by no means representative of a modern service economy, we use Kotlikoff and Wise's (1989) salary measures of office workers for our second estimate of age-specific labor productivity. The difficulty here is that salaried workers' pay generally encompasses a major seniority element which severs the tie between pay and productivity across the life cycle. Figure 10 shows this phenomenon quite clearly: the pay of "novices" is significantly lower than that of the "old hands". The sharp fall which takes place once the age of 60 has been reached is almost certainly a statistical artifact, however, as most of the salaried workers employed by this company take early retirement. The earnings of novices however once again reveal a strong age link. We draw on this age - salary pattern of newly recruited staff as our second estimate for the age-specific 
labor productivity of salaried workers. This turns out to be considerably "curvier" than the profile shown in figure 9.

Figure 10: Age and seniority-specific earnings of salarymen

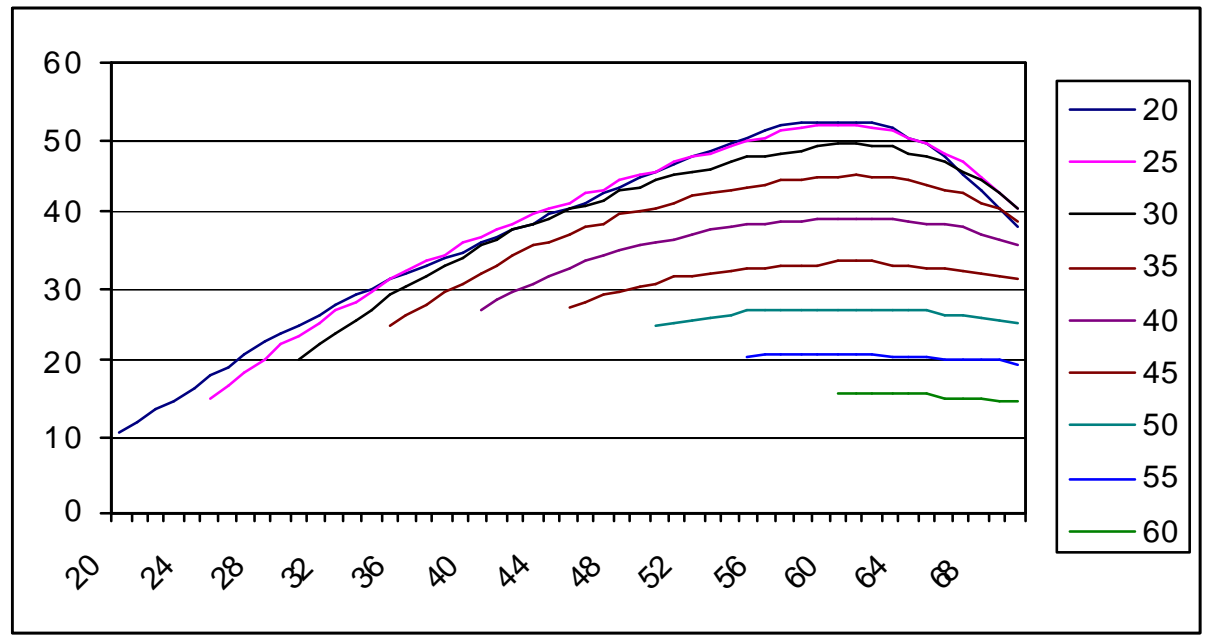

Source: Kotlikoff and Wise (1989)

Figure 11 shows the normalized age-productivity estimates. Both feature a distinct bell-shaped curve which peaks for salaried workers at the age of 44 years and subsequently falls rapidly while sales employees' productivity maximum is reached 4 years later and is much less pronounced. In both cases, labor productivity is about $20 \%$ of its lifecycle maximum at around 16 years and sinks back down to this level again at 75 years. 
Figure 11: Relative labor productivity of salesmen and salarymen

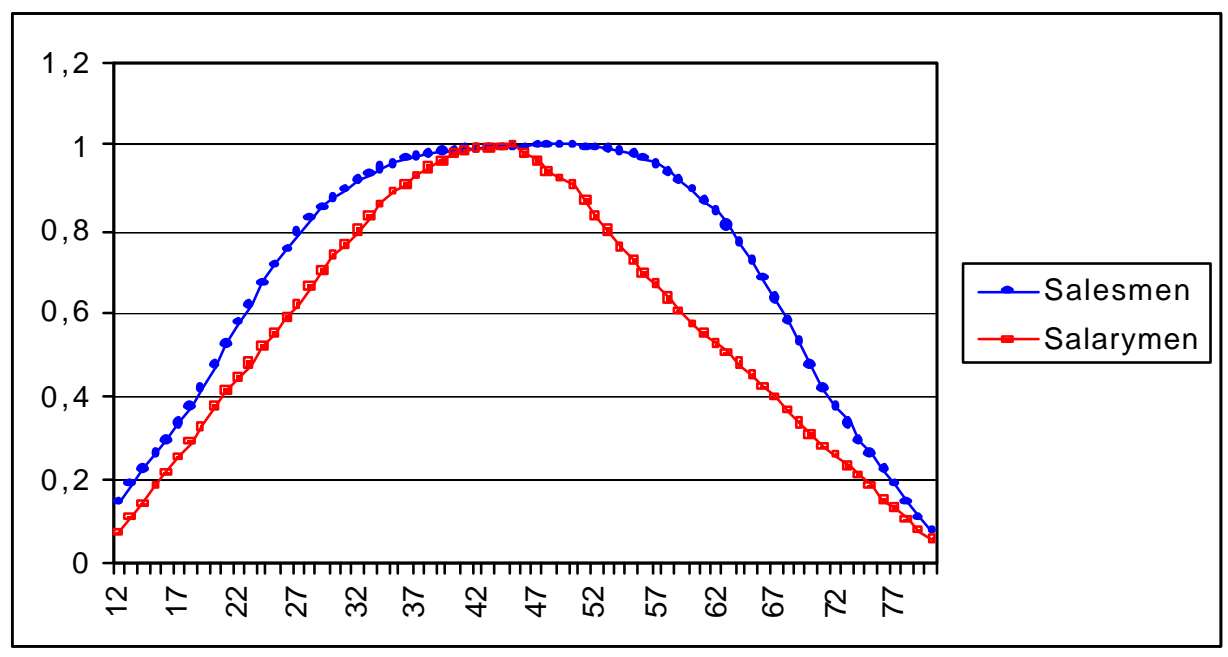

Source: Derived from Kotlikoff and Wise (1989)

The point of this exercise becomes clear in Figure 12. We now multiply age-dependent productivity (Figure 11) with the gradually changing distribution of the age structure of the working population (Figure 7) in order to calculate the time path of the aggregated productivity of the labor force.

Figure 12: Potential effect of age-specific labor productivity on aggregate labor productivity

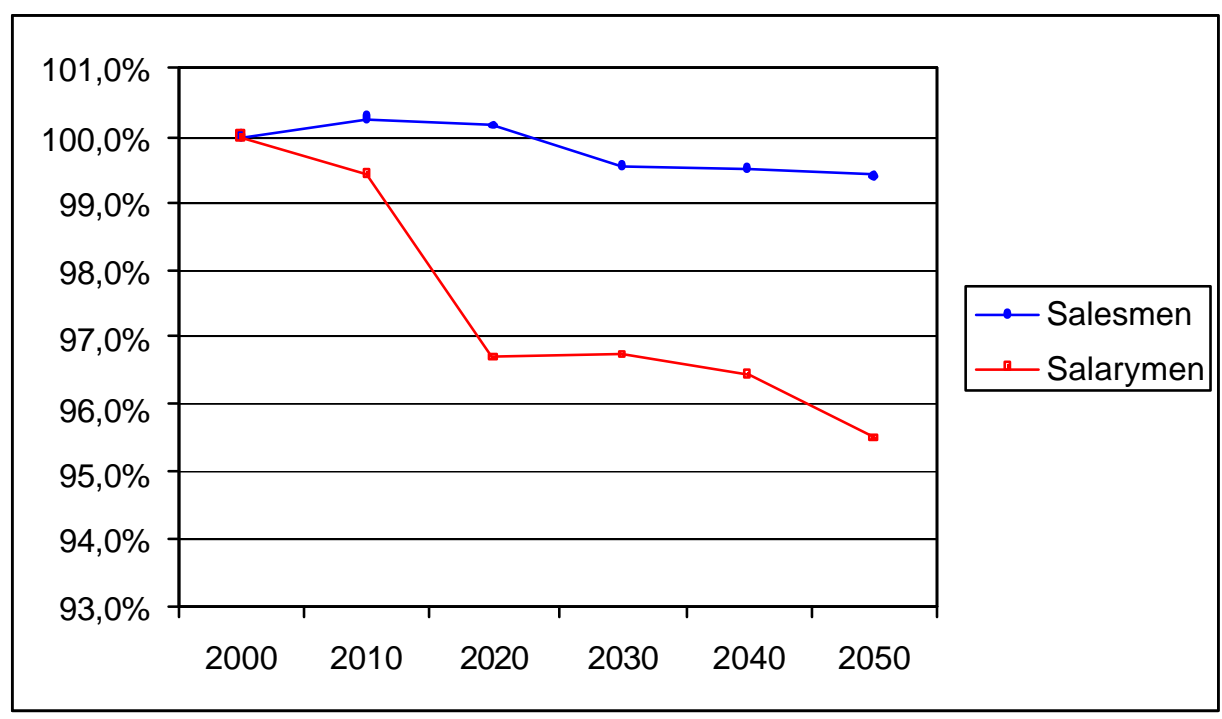

Source: Own calculations 
The main lesson from this exercise is that makes a considerable difference whether figure 9 or 10 is assumed to be the true age-productivity profile. If the age-productivity profile looks like figure 9 , there is no severe impact of aging on aggregate labor productivity. If the age-productivity profile, however, is better described by figure 10, aggregate labor productivity will significantly drop, amplify the negative effects on economic growth, and exacerbate the divergences through global aging.

More research on age-specific productivity is clearly needed to better understand whether aging economies will suffer from a productivity decline, amplifying the effects of a shrinking quantity of labor. At the very least, the difference between figures 9 and 10 indicates the value of policies fostering further education. Similar arguments apply to the innovative capacity of aging societies.

\section{Interactions between Labor, Product and Capital Markets}

The labor market is not insulated from other markets. It is not only directly affected by population aging, but also indirectly by aging-induced changes in product and capital markets. In this brief interim section, we first focus on interactions between labor and product markets, then on interactions between labor and capital markets.

\subsection{Interactions between labor and product markets}

Product demand will change, since an older population of consumers has different preferences and needs than a younger population. Consumption demand may also decline for at least two reasons. First, because GDP per capita will decline in the face of a shrinking labor force unless this is offset by higher capital input and productivity. Second and more subtly, it is likely that more retirement income comes from asset income which fluctuates more than annuitized pension and labor income. This will increase precautionary savings and depress consumption, given a fixed level of income. We have little evidence to quantify these effects so far. 
Somewhat easier to predict are shifts within consumption demand. Consumption behavior changes with increasing age. As an illustration, figure 13 shows the age-specific shares of nine broad expenditure groups specified in the 1993 German Income and Consumption Survey ("EVS 1993”). It is noticeable that spending on goods in the group "transport and communication" falls over the life cycle while goods in the "health and hygiene" group, as well as costs of shelter, account for a growing share of older households' budgets.

Figure 13: Age-specific distribution of consumer spending across different group of goods

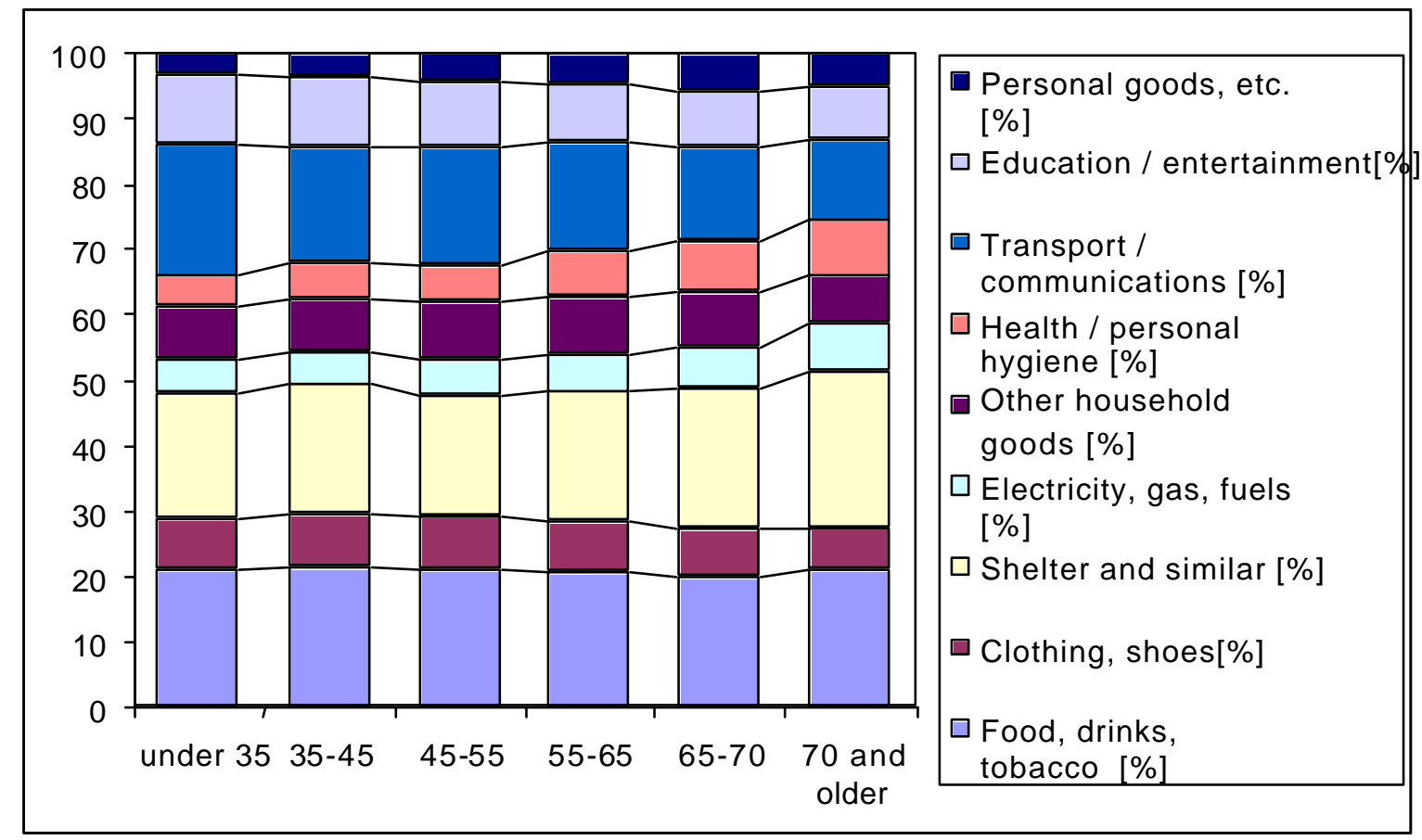

Source: Federal Statistical Office, Survey 15, No. 5, EVS 1993.

Hence, if the age distribution of an economy is changing, the composition of consumption will change accordingly. As a simplistic first approximation, we may assume that the pattern of age-specific consumer spending shown in figure 13 remains much the same in the future. Then one can apply a simple shift-share me thodology to predict consumer spending by sector of demand. This is done by multiplying age-specific expenditures with the age-group figures provided by a population projection. Most notably 
the aggregated expenditure on health calculated on this basis will increase during the aging process while the corresponding spending on transport will decline.

Changing product demand will then precipitate shifts in sectoral labor demand. Two questions arise: How large are these shifts? And, more important for an assessment of global aging, which countries will profit from these changes, and which countries will suffer from them?

Using again a simplistic shift-share methodology to obtain a rough idea of the potential order of magnitude, we arrive at the changes in sectoral employment depicted in figure 14. It is computed by multiplying the expenditure projections with current sector-specific labor productivity to arrive at the time path of workers per sector in the course of population aging. Figure 14 displays the results as deviations from sectoral labor demand in the year 2000. Employment in the health sector will increase by around 7\%. It will fall in the transport sector by around 5\%. Overall, increases and decreases in employment amount to a total of 18 percent, suggesting that more than a sixth of all workers will need to change their jobs due to population aging.

Figure 14: Increase/decrease in employment per goods sector




Source: Own calculations based on figure 13, population projection B2, and the annual abstract of statistics "turnover per worker" in each sector.

This simplistic approach may lead to rather biased results if age-specific consumption patterns will change. Age-related consumption patterns are an under-researched area. Usually (as in figure 13), agespecific consumption behavior is inferred from cross-sectional data. Such data, however, confound age, cohort and time effects. They can only be separated using panel data on the structure of spending, or, with some approximation, by using repeated cross-sections to form a synthetic panel (Deaton and Paxson, 1994). There is little research on past changes in consumption patterns, using such data, and subsequent implications for an aging population.

\subsection{Interactions between labor and capital markets}

Labor supply is also affected by capital market fluctuations. The more retirement income is provided through funded pension income (e.g., 401k plans or other individual accounts invested in the stock market), stock market performance will, at the margin, affect the retirement decision of workers as well as their consumption demand. While there is some evidence that the recent increase in retirement age is concurrent with the decline in stock market values, see figure 15, taken from Eschtruth and Gemus (2002), these data are too recent and cover too short a period to permit causal analysis.

Figure 15: Stock Market Performance and Labor Force Participation of Older Persons 


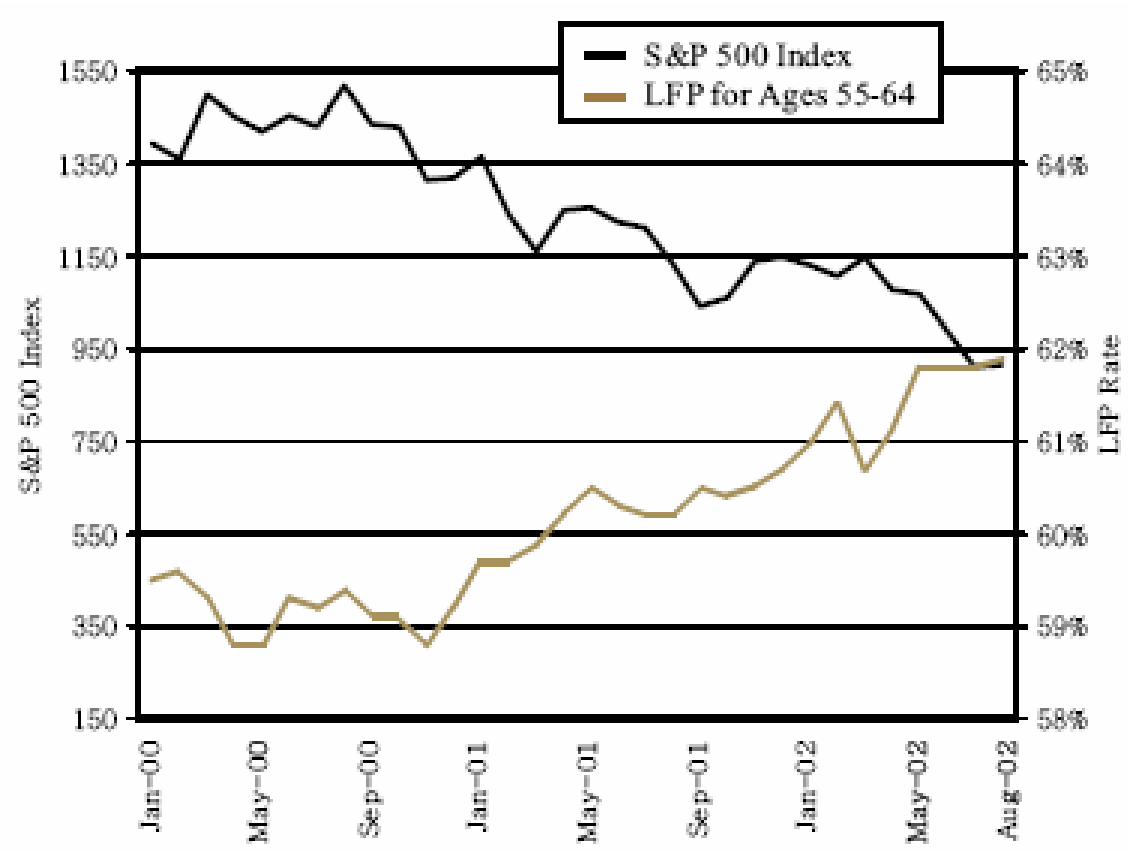

Source: Eschtruth, A.D., and J. Gemus (2002)

Understanding this mechanism is important for analyses of global aging since it may substantially amplify capital market disturbances. Stock markets have exhibited huge swings, and we do not fully understand how bubbles emerge and even less how to predict and prevent them. There is little convincing literature so far to assess in how far labor supply adaptations such as postponement of retirement moderate or amplify the negative implications of stock market fluctuations. One route for such analysis would be the rejuvenation and adaptation of real busin ess cycle models. This topic has a clear political dimension since the flexibility of choosing the retirement age is a core transmission mechanism for these interactions between the capital market on one side and labor and product markets on the other side.

\section{Capital markets}

Capital markets play a crucial role in global aging since capital is the factor which moves with the least frictions across countries, and it permits to shift resources from one period to another. The first mecha- 
nism permits international diversification of demographic risks, the second mechanism permits intertemporal (even intergenerational) substitution of resources.

Both issues are complicated in a system of many countries, some of them aging faster than others, some of them not aging at all. There will be competition across the aging regions for profitable foreign direct investment in regions that age slower or not at all. An important area of research is therefore to gauge the relevant orders of magnitude in a system of regions which is tied together by flows of capital combined with reverse flows of goods and services.

Capital market issues cannot be studied in isolation from public policy. Most importantly, the share of private pensions in total retirement income is a major determinant of the supply of loanable funds. Fundamental pension reform has therefore a large impact on capital markets. In turn, the future performance of capital markets will have a huge impact on the success of the current generation of pension reforms. If rates of return stay low, or if an "asset meltdown" will occur due to falling asset values when the baby boomers retire, funded pensions will not provide the much searched for escape from the demographic problems that plague the public pay-as-you-go pension systems.

There is a host of time-honored and fundamental research questions in this area which still bear a host of unanswered questions. ${ }^{4}$ One set of issues concerns the effect of public pensions on aggregate savings and, more subtly, on the composition of aggregate savings. There are actually two distinct issues: crowding out of savings by public pay-as-yourgo financed pensions, and crowding out of general savings (say, for the down payment of a home) by retirement savings. Another set of issues is the extent of international diversification. While we know that there is strong home bias and while we know that capital does not move freely, we do not have reliable calibrated models of capital market frictions. We also do not fully understand how portfolio choice will evolve in the future since we have competing explanations of the equity premium. Compositional changes of financial assets, however, are likely in the face of population aging. Finally, capital markets contribute to productivity and thus growth of the entire economy. A

\footnotetext{
${ }^{4}$ See the companion survey paper in this workshop by Bosworth, Bryant and Burtless (2004).
} 
direct channel is corporate governance which is likely to be affected by pension policy and by the mechanisms that institutional investors use to funnel retirement funds through the economy.

So far, we understood capital markets as markets for real capital (as a factor of production). We have a set of reasonably well-working models for the accumulation of real capital. Departing from Solow-type growth models (Cutler, Poterba, Sheiner and Summers, 1990), we now usually use models of overlapping generations (OLG) in the tradition of Samuelson and Diamond. ${ }^{5}$

OLG models have recently been extended to multicountry settings suitable to study global aging. OLG models have been used to analyze international capital flows since the seminal contribution by Buiter (1981). More recently, several authors have developed large-scale multi-country OLG models to study the effects of population aging and pension reform on international capital flows. Attanasio and Violante (2000) and Brooks (2003) analy ze demographic effects on international capital mobility in stylized models (and in the case of Attansio and Violante, using also very stylized demographic projections). Both papers do not address the important issue of pension reform with its associated change in saving patterns. NGENUE (2001) and Börsch-Supan, Ludwig and Winter (2002) also address issues related to pension reform, and they use actual demographic projections which model population aging realistically as a more than one-dimensional event. Börsch-Supan, Ludwig and Winter (2004) show that the delicate effects of the differential timing of demographic change across countries on macroeconomic aggregates and capital flows can only be assessed with actual demographic forecasts; they are largely ignored in the stylized demographic transition schemes used in other work, and only coarsely modeled in INGENUE (2001).

These "global aging models" are fairly sophisticated by now and can be calibrated to real data. However, they ignore national and international capital market frictions so far. For the lack of a better model of capital mobility (see subsection 5.4), we will restrict attention to OECD countries, and we will, in the

\footnotetext{
${ }^{5}$ Samuelson (1958); Diamond (1965), then Auerbach and Kotlikoff (1987). Recent examples include Kotlikoff, Smetters and Walliser (1999), De Nardi, Imrohoroglu and Sargent (1999), and Altig, Auerbach, Kottlikoff, Sme tters and Walliser (2001) for the United States, Miles (1999) for Great Britain, and Fehr (2000), Hirte (2002) and Börsch-Supan, Heiss, Ludwig and Winter (2003) for Germany. Miles and Iben (2000) present a comparative analy sis of pension reform
} 
example provided below, only model the polar cases of a closed economy and of perfect capital mobit ity within the OECD region. This approach allows to understand the effects of capital mobility on rates of return in the future even though the true effect might be smaller. More research on capital market frictions will help, to better understand how international diversification might alleviate the negative implications of global aging.

A major issue not yet sufficiently tackled with is also the treatment of risk in OLG models. With the exception of Attansio and Violante (2000) and Börsch-Supan et al. (20xx), existing studies such as INGENUE (2001) and Brooks (2003) have not addressed the impact of life-time uncertainty on household saving decisions. This is not only an important and salient extension of the classical life-cycle theory of consumption. Not including the underlying survival rates in the household problem also leads to inconsistencies in aggregation. Income and capital market risks, however, have not been modelled so far in realistic OLG models.

Markets for real capital are, of course, linked to financial markets with their large risks and uncertainties. We know much less about the modeling of financial markets, in particular international financial markets, once they deviate from the fundamentals given by the demand for, and the supply of, real capital. We have some theoretical models of bubbles, but we are far from a understanding, not to speak about modeling, of how financial market shocks are transmitted through the global economy. One might argue, that the effect of global aging is on real capital only, since demographic change is a slow and steady devel opment. This is the basic assumption when OLG models are used to predict future capital flows and rates of return. One may also argue that the increasing reliance on capital markets through private pension may increase the potential for nervous reactions, sparking financial crises more often in a globalized and aging world than in the previous decades with segregated financial markets and little leverage of pension funds. Case study type of research on the behavior of pension funds in critical situations may be important to identify mechanism that stabilize financial markets and ultimately strengthen confidence in funded pensions.

schemes for the United Kingdom and Germany. Kotlikoff (2000) provides an overview of earlier applications of overlapping generations models. 
In the sequel of this section, we focus on five important capital market questions about global aging which would benefit from more research but where we have already some interesting qualitative (and sometimes even quantitative) results.

\subsection{The supply of savings}

Does global aging decrease the supply of global capital? Theoretical arguments that establish this link build on the well-known life-cycle theory of consumption and savings by Modigliani, Ando and Brumberg (Modigliani and Brumberg, 1954; Ando and Modigliani, 1963). The aggregation of individual, cohort-specific life-cycle savings profiles leads to a decrease of national saving rates in an aging economy. In a general equilibrium model of forward-looking individuals, it is not only the current demographic structure that alters the time path of aggregate savings, but also future demographic developments. There are two main channels for effects of demographic change on domestic capital formation. First, decreasing labor supply reduces demand for investment goods since less capital is needed. Second, in a closed economy, a decline in national savings leads to a decline in investment by definition. In an open economy, the link between these two aggregates is broken to the extent that capital is internationally mobile.

While the theory is straightforward, it is less clear to which extent the stylized microeconomic savings theory by Modigliani applies to reality. Figure 16 shows German saving rates by age (corrected for cohort effects). While we recognize the hump-shape predicted by Modigliani, we do not observe any dissaving in old age. 
Figure 16: Age-specific saving rates (cohort corrected)

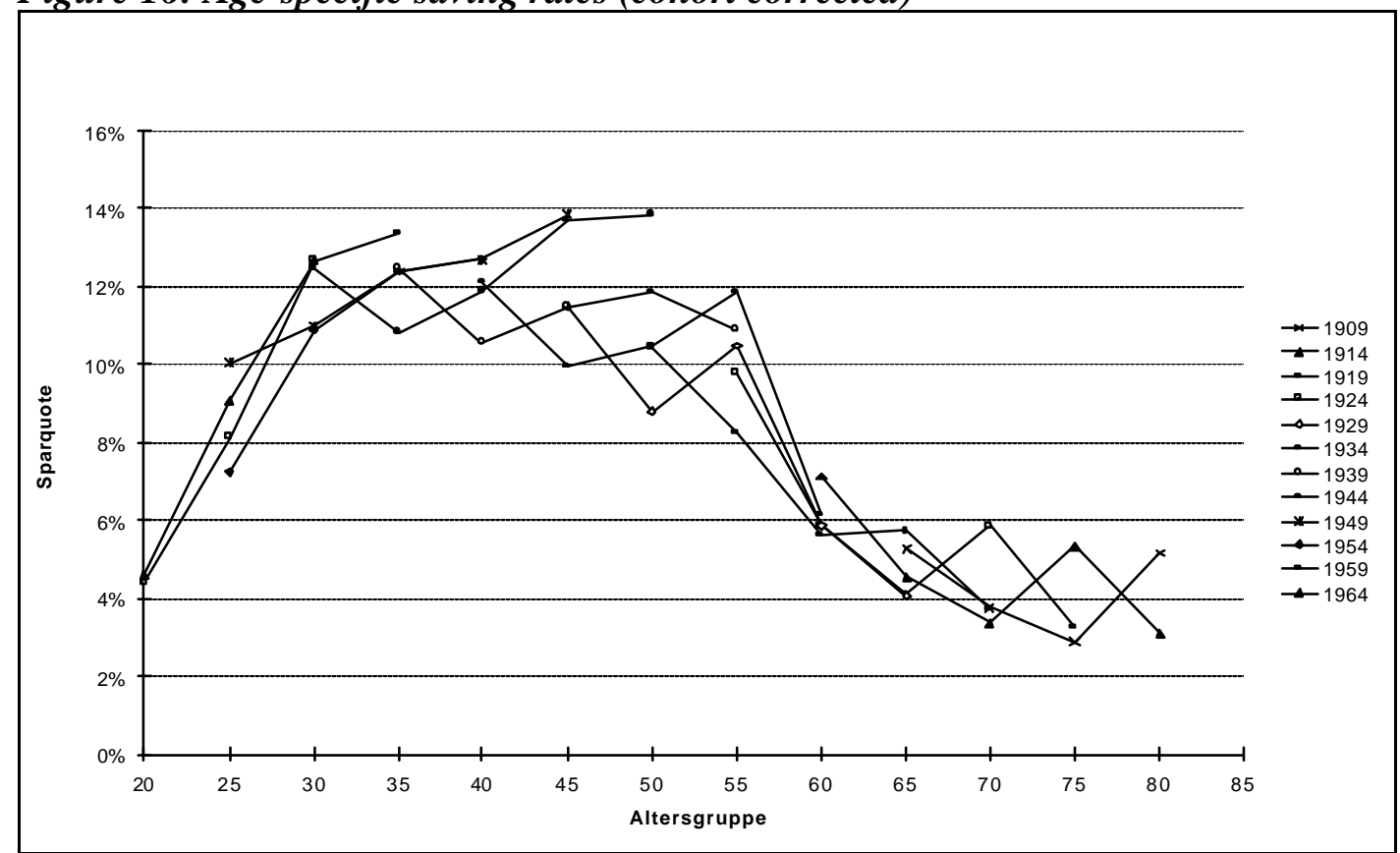

Source: Börsch-Supan, Reil-Held and Schnabel (2003)

This sheds considerable doubt on the realism of predictions based on the simple life cycle hypothesis. Such predictions are likely to overestimate the decline of saving rates if the true saving behavior looks more like figure 16. We do not know much, however, about how the current saving behavior might change in the face of global aging. In particular, pension reform away from pay-as-you-go-financed pensions towards funded pensions might change saving behavior because it revives the retirement saving motive. To understand this, we need cross-national studies on saving behavior, since only international comparisons provide the policy variation needed for such analysis.

The potential power of such studies can be seen in figure 17 which shows, by age group, median saving rates in France, Germany, Italy and the Netherlands. They are based on a comparable longitudinal framework, represent life-cycle saving purged from cohort effects, and employ comparable variable definitions and data sources as part of the International Saving Comparisons Project (Börsch-Supan, 2001). 
Figure 17: Age-specific saving rates (cohort corrected)

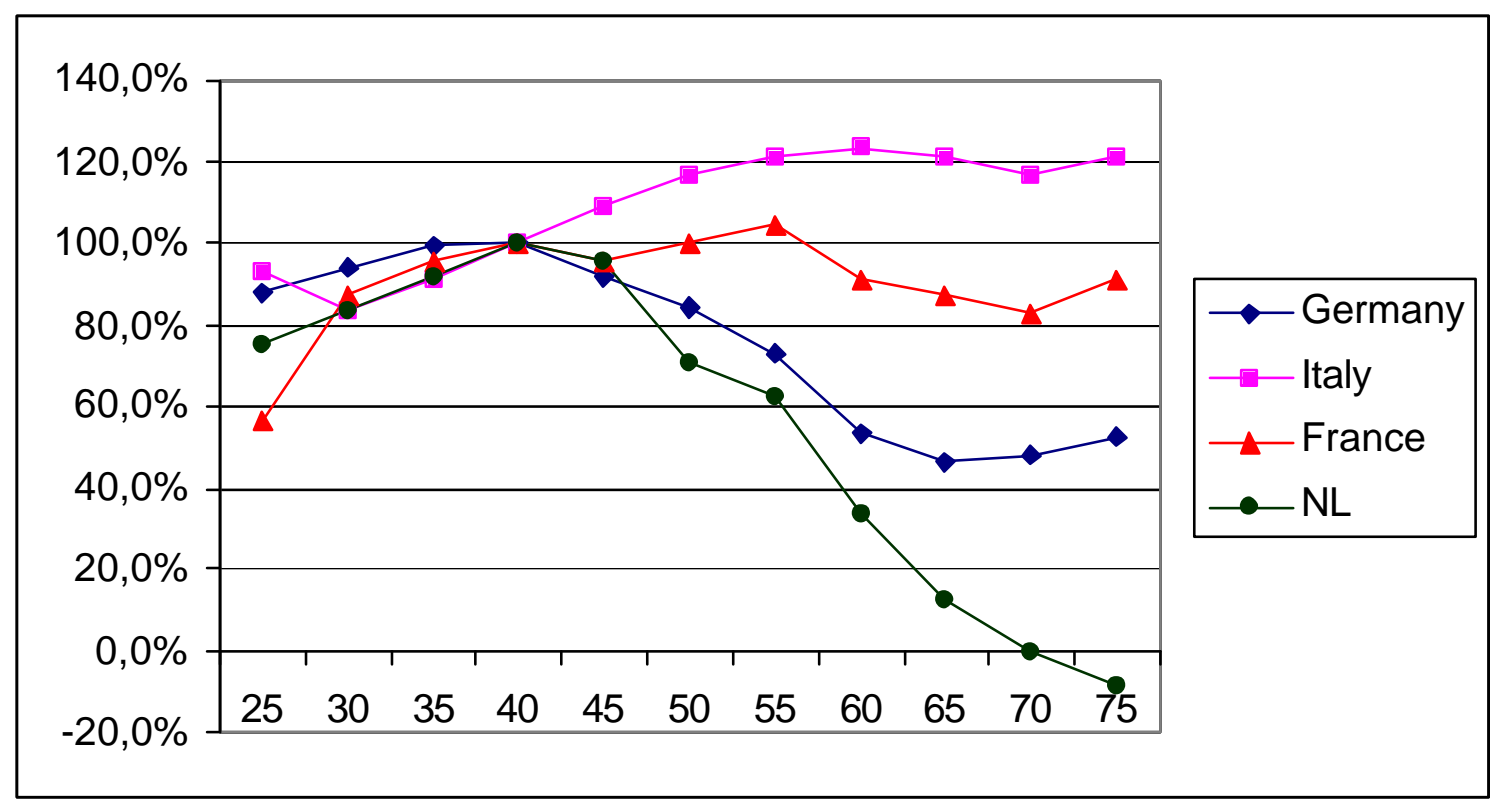

Sources: France: Fall, Loisy, and Talon (2001); Germany: Börsch-Supan, Reil-Held, Rodepeter, Schnabel, and Winter (2001); Italy: Brugiavini and Padula (2001); Netherlands: Alessie and Kapteyn (2001).

The saving profiles in France, Germany and Italy are rather flat and show no dissaving in old age. One possible explanation is that the high replacement rates of the public pension systems in these countries have made private retirement income largely unnecessary. ${ }^{6}$ If other saving motives, such as precaution and intergenerational transfers, are more important than retirement saving, age-saving profiles are likely to be much flatter than under the textbook life-cycle hypotheses which predicts saving in young and dissaving in old age. This explanation is in line with the work by Jappelli and Modigliani (1998) who argue that the main mechanism for "retirement saving" in Italy is the PAYG system. While we lack the most appropriate counterfactual - French, German and Italian data from times when these countries had no PAYG systems figure 17 depicts the case of the Netherlands which have, as opposed to France, Germany and Italy, only a small base pension provided by their PAYG public pension system. All additional retirement income in the Netherlands has to be provided by (mandatory) savings plans, commonly provided through occupational

\footnotetext{
${ }^{6}$ See Boeri, Börsch-Supan and Tabellini (2001) for a comparison of replacement rates.
} 
pension plans. Figure 17 shows that the median Dutch household has a much more pronounced humpshaped life-cycle savings profile than the median French, German and Italian households, and it exhibits dissaving among the elderly as they draw down their mandatory saving accounts.

This cross-national microeconomic evidence suggests that the consumption-smoothing mechanism employed in the OLG model may be a quite appropriate prediction device. A pension reform towards a multipillar system with a substantial portion of funded retirement income will revive the retirement motive for saving in France, Germany and Italy. In fact, these systems will look very similar to the current Dutch system. Hence, it is likely that saving rates among the young will increase (to accumulate retirement savings), and saving rates among the elderly will decline sharply (because they will dissolve their retirement savings). ${ }^{7}$

Empirical evidence on how demographic change has affected saving behavior across countries in the past is reviewed by Poterba (2001). Following earlier work by Higgins (1998) and others, Lührmann (2002) investigates whether demographic factors have influenced international capital flows in the past. She uses a broad panel of 141 countries that covers the period 1960-1997 to investigate the effects of demographics on international capital flows. She confirms that cross-country capital flows are indeed influenced by demographic variables. While this has been shown in other studies before, she can also show that relative differences in the age structure across countries are the most important determinants of capital flows. Moreover, as Lührmann (2002) shows, future changes in the age structure of countries are important determinants of current saving and investment decisions, a finding that confirms forwardlooking household behavior.

The effects of international diversification on savings behavior and its interaction with pension reforms receive rapidly increasing attention as the pension reform debate progresses. Deardorff (1985) contains an early analysis, and Reisen (2000) provides a comprehensive overview of these issues. Reisen argues strongly that there are pension-improving benefits of global asset diversification. In a theoretical paper,

\footnotetext{
${ }^{7}$ Portfolio composition is also likely to change under such a shift, see section 5.3.
} 
Pemberton (1999) highlights the importance of international externa lities caused by the effects of mational pension and savings policies on the world interest rate. Pemberton (2000) goes a step further and shows that an intergenerational Pareto improvement through coordinated pension reforms is possible.

Sophisticated OLG models are in principle able to predict many of the above effects, although they are so far - not correctly taking the risks and uncertainties into account which generate precautionary savings. The models mainly capture savings accumulated for long-run consumption smoothing, especially for retirement. Figure 18 shows the output of such a model (Börsch-Supan, Ludwig and Winter, 2004) for Germany as part of an EU and an OECD-wide open capital market. We display six variants. In order to show the effect of global capital markets, the three lines in each figure represent the case of Germany as a closed economy, a two-region world consisting of Germany and the other EU countries with free capital mobility between the two regions, and a two-region world extended to all OECD countries. In order to separate the direct effect of population aging and the additional effects of pension reform, we present all projections under the traditional PAYG system and then show the additional (differential) effect of a pension reform that induces a substantial extent of pre-funding by freezing the contribution rate to the PAYG pillar. In an OLG model, pre-funding will happen automatically through the consumption smoothing mechanism. The transition process eventually leads to a state in which about one third of retirement income will come from the funded pillar. 
Figure 18: Projections of the German aggregate saving rate under alternative pension systems and capital mobility scenarios

Pre-2002 pension systems

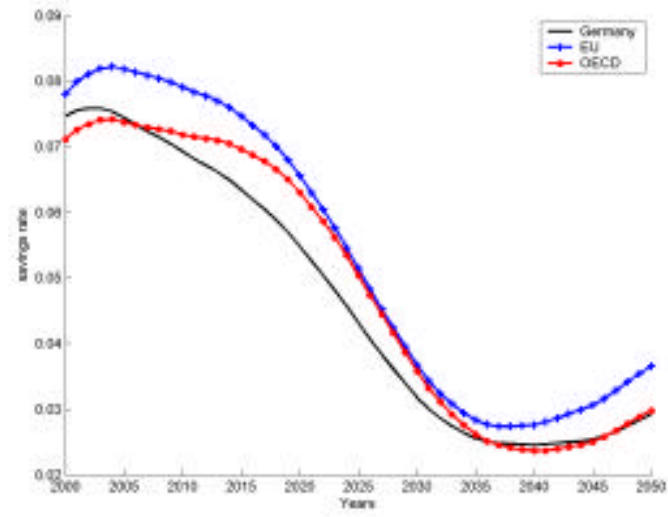

After fundamental pension reform

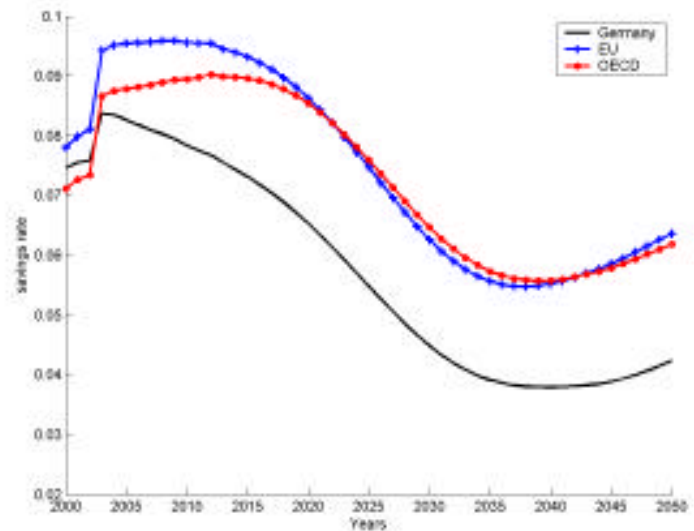

Notes: This figure shows projections of the aggregate savings of German households as a percentage of GNP. Pension reform only in Germany. Germany: Germany as a closed economy, EU: perfect capital mobility in the EU area, OECD: perfect capital mobility in the OECD area.

Source: Own calculations, based on demographic projections of the United Nations (2000) and age and genderspecific labor force participation rates by the OECD (2002).

The aggregate saving rate decreases throughout the entire observation period in all capital mobility scenarios since the baby boom generation decumulates assets. When the aging problem peaks in Germany around 2035-2040, the saving rate reaches its trough. The decrease of the savings rate caused by population aging - the difference between the value in 2000 and the minimum reached in 2035-2040 - is about 5 percentage points in the closed-economy and EU 14 scenarios and 4.7 percentage points if we allow for capital mobility within the OECD. The projected aggregate saving rates under a fundamental pension reform are substantially higher and the effect of a pension reform is stronger in the two openeconomy scenarios. An increase in national savings leads to an increase in the capital stock and thereby to a decrease in the rate of return to capital which then crowds out further savings. In the open-economy scenarios, substantially more savings is generated since - as we show below - the rate of return decreases by much less. 
These projections show that optimal life-cycle behavior generates additional saving under a fundamental pension reform - in our model, it is not the case that additional retirement saving induced by a pension reform crowds out other saving totally, as often claimed. Some crowding out does take place. Our projections indicate a substitution of about one third, leaving two thirds to new saving. The extent of crowding out is of course very important to understand in order to estimate future global capital supply. International comparisons such as illustrated in Figure 17 provide the necessary policy variation and are therefore important research tools in order to better understand the crowding out of private savings by public programs.

\subsection{Asset meltdown?}

Several articles in the popular press have attributed recent rises in stock market prices to population aging and raised the fear that an asset market melt-down might occur when the baby boom generation decumulates its assets. In the academic literature, there is no consensus on the asset market melt-down hypothesis (see e.g. Poterba, 2001; Abel, 2001; and Brooks, 2002). According to our view, closedeconomy models conventionally used in the academic literature miss the important fact of international capital flows under global aging. Because of international diversification, the melt-down of the asset market is lower than predicted by closed-economy versions of conventional OLG models. Börsch-Supan, Ludwig and Winter (2004) show that the decrease in the rate of return which results from both population aging and moving towards pre-funded pensions is modest, approximately 1.4 percentage points once we assume a closed economy. The return on capital can be improved by international diversification, that is, by investing pension savings in countries with a more favorable demographic transition path than Germany. 


\section{Figure 19: Projections of the rate of return to capital under alternative pension systems and capital mobility scenarios}

Pre-2002 pension systems

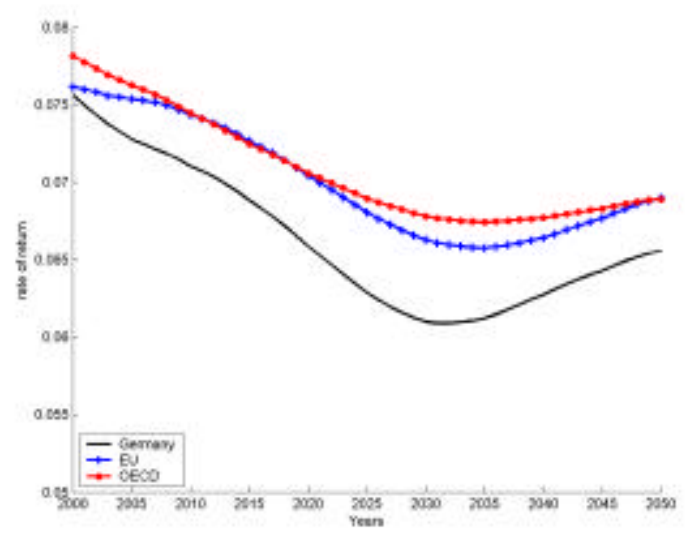

After fundamental pension reform

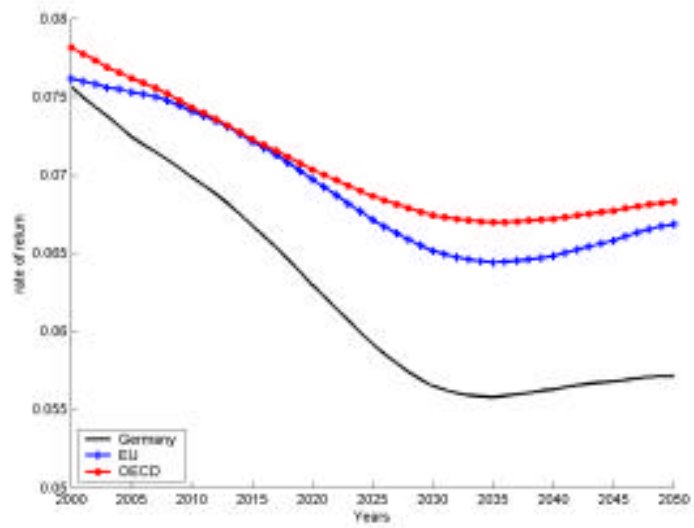

Notes: This figure shows projections of the rate of return to capital. Pension reform only in Germany. Germany: Ge rmany as a closed economy, EU: perfect capital mobility in the EU area, OECD: perfect capital mobility in the OECD area.

Source: Own calculations, based on demographic projections of the United Nations (2000) and age and genderspecific labor force participation rates by the OECD (2002)

The left panel shows that a decrease in the rate of return on capital is evident for both the closedeconomy and the two open-economy scenarios. However, the decrease is much less than often claimed in the public debate. Even in the closed-economy case, a decrease of the rate of return of about 1.4 percentage points - as measured by the difference between the rate of return in 2000 and the minimum for the period 2030-2040 - is much less than often claimed in the public debate. Moreover, it is apparent that closed-economy models overestimate this reduction of the rate of return: its projected decrease is only about 1 percentage point for both capital mobility scenarios. In absolute terms, this is not a very large difference (even though the compound effect, over two or three decades, of even such a small difference matters when it comes to analyzing funded pension systems).

The beneficial effects of openness to international capital markets become much more evident when we analyze the effects of a fundamental pension reform. If a fundamental pension reform was implemented in Germany and if Germany was a closed economy, then the additional decrease of the rate of return to capital would be about 0.8 percentage points. But as the right panel shows, there is virtually no differ- 
ence of the rate of return between the two pension system scenarios if capital is freely mobile within the OECD. In the intermediate case, when capital mobility is restricted to the EU area, the decrease would only be around 0.2 percentage points.

This interaction between global aging and pension reform is an important finding. It suggests that household savings induced by a fundamental pension reform should be invested internationally, not only for reasons of risk diversification (which of course are not present in our deterministic model), but also for the sake of higher returns that are available in other countries with different aging processes and more favorable capital/labor ratios. Our results also confirm our earlier claim that the most important beneficial effects of capital mobility do already show up under very modest capital mobility scenarios. Indeed, there is almost no difference between the OECD scenario and a scenario where we allow for perfect capital mobility in the entire world (results are not shown).

\subsection{Portfolio choice and differential rates of return}

It is unlikely that all assets are equally affected by global aging. In addition to the international differences in domestic returns, to be equalized by international capital flows as discussed in next section, it is likely that the demand for safe assets will increase relative to risky assets, simply because an older population tends to prefer safe assets because they have less time left to compensate for economic shocks.

The development of models which are able to generate robust predictions of portfolio choice and differential rates of return is still in its infancy. A major obstacle is the less than perfect understanding of the equity premium puzzle, and the difficulties in modeling dynamic portfolio choice over the life cycle („Consumption Capital Asset Pricing Model“, CCAPM; Lucas, 1978). Modern versions of these models (Bodie, Merton und Samuelson, 1992; Campbell und Viceira, 2002) are mathematically complicated but nevertheless still fairly simplistic in their underlying economics and do not yield robust predictions; i.e., small changes in the underlying assumptions create large deviations in the predicted outcomes. Brooks (2003) uses a very simplified version of such models to predict a population aging-induced increase in the difference between the returns to safe and risky assets. 
To be realistic, these models need to solve the "equity premium puzzle", i.e., a larger return difference between safe and risky assets than warranted under simple models of risk aversion (Mehra und Prescott; 1985). One method, due to Constantidines, Donaldson und Mehra (2002), imposes credit restrictions (in form of a fixed percentage of household disposable income). Following this approach, BörschSupan, Ludwig and Sommer (2003) embed a calibrated dynamic portfolio choice model into an overlapping generations model in order to differentiate the results discussed in the preceding subsection (see figure 19) by safe and risky assets. Figure 20 summarizes the main results.

Figure 20: Projections of the rate of return: riskiness

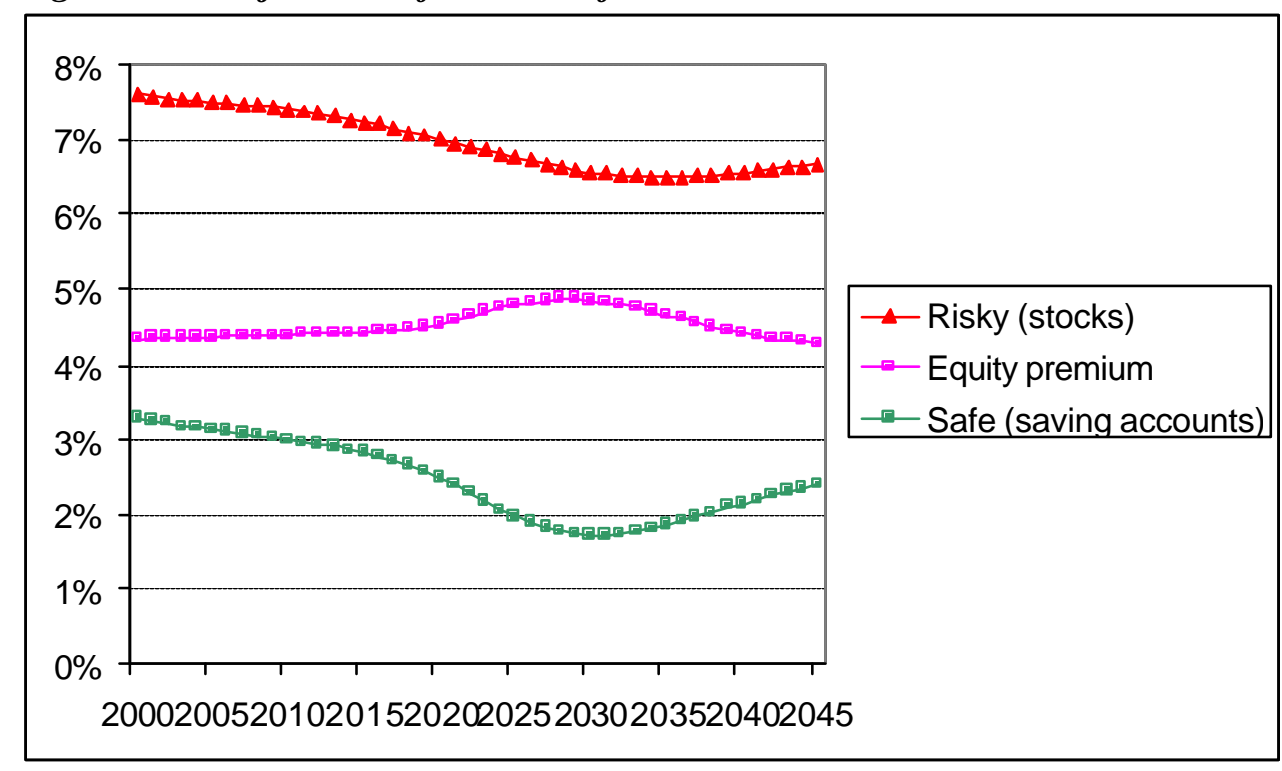

Source: Börsch-Supan, Ludwig and Sommer (2003)

The risk-free rate is predicted to decrease relatively sharply during the next 25 years from 3.3 percent to a little above 1.8 percent in the year 2027. This decline is much stronger than the decrease in the rate of return of stocks ( 7.6 to 6.8 percent). After 2027, the rate for safe assets increases again, while the rate for stocks remains essentially stable. The equity premium increases until 2025 to about 70 basis points. This effect, however, is only temporary. The equity premium goes back to the pre-aging figures to the extent by which the baby boomers convert their safe assets into consumption. 
These results are to be taken with caution; they are more qualitative than quantitative projections. Figure 21 shows their large sensitivity to assumptions about the underlying exogenous growth rate on the OLG model. The results are equally sensitive to specifications of the extent of credit rationing, generating the equity premium puzzle mechanism. The international perspective is still missing in this model. Obviously, more research is needed to truly understand how the rates of return of safe and risky assets are affected by global aging.

Figure 21: Projections of the rate of return: sensitivity

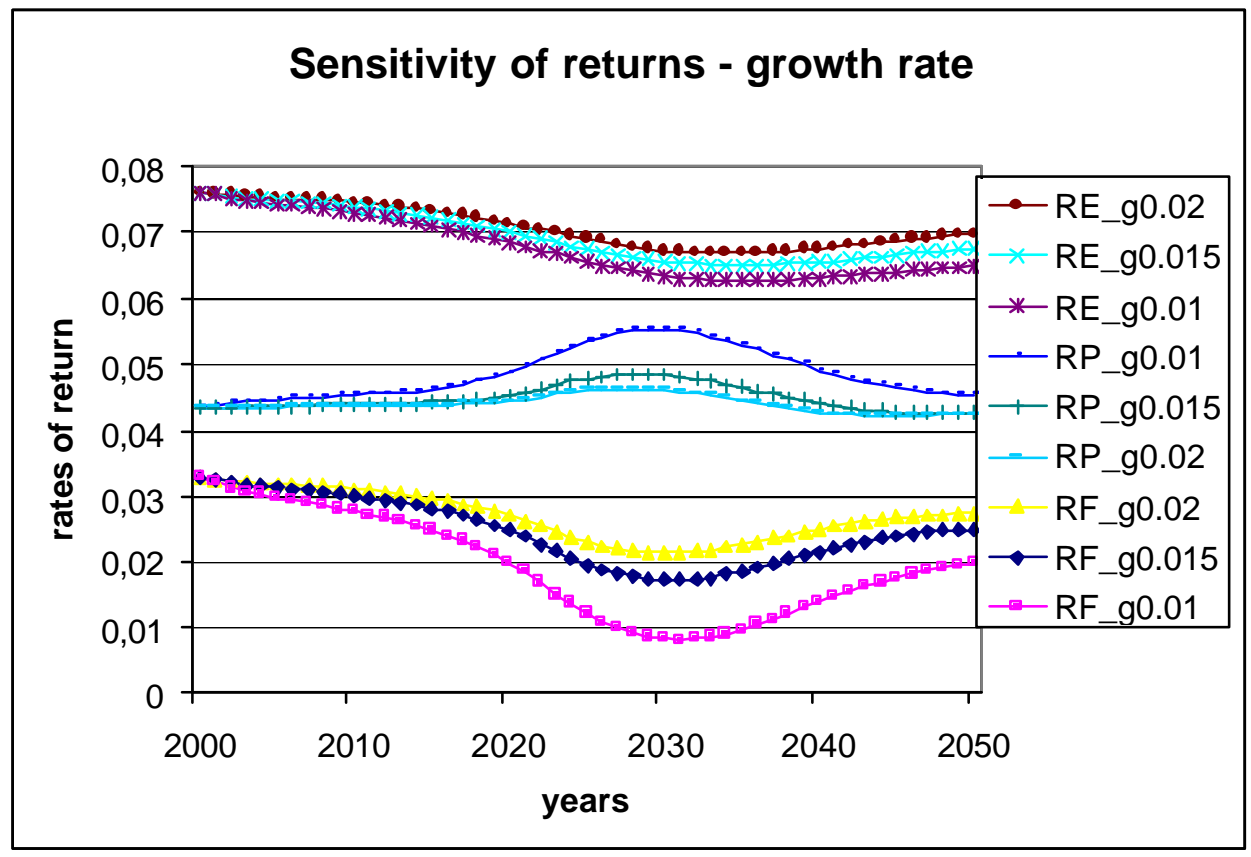

Source: Börsch-Supan, Ludwig and Sommer (2003)

\subsection{International capital flows}

It is well known that within each country, demographic change alters the time path of aggregate savings, even more so in countries where fundamental pension reforms - that is, a shift towards more pre-funding - are implemented (Börsch-Supan 1996; Reisen, 2000). To the extent that capital is internationally mobile, population aging will induce capital flows between countries. Figure 22 shows net capital exports of 
different regions within the OECD as a percentage of GDP. As the left panel indicates, a international OLG model is able to generate capital flows of the correct sign not only for Germany, but also for the other world regions, especially the United States and Japan. As mentioned before, levels are however overestimated. Given that the US will continue to have a younger population than other regions, it will also continue to be a capital import country. For Japan the opposite holds.

Figure 22: Projections of net capital exports of the OECD area under the assumption of perfect capital mobility within the OECD

Pre-2002 pension systems

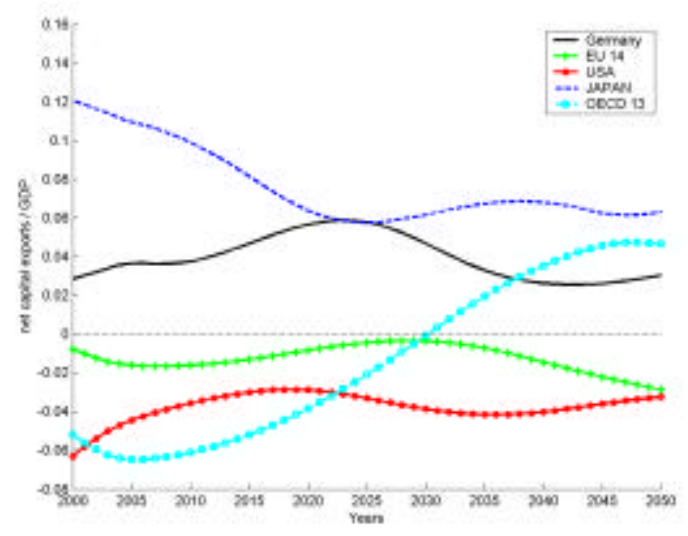

After fundamental pension reform

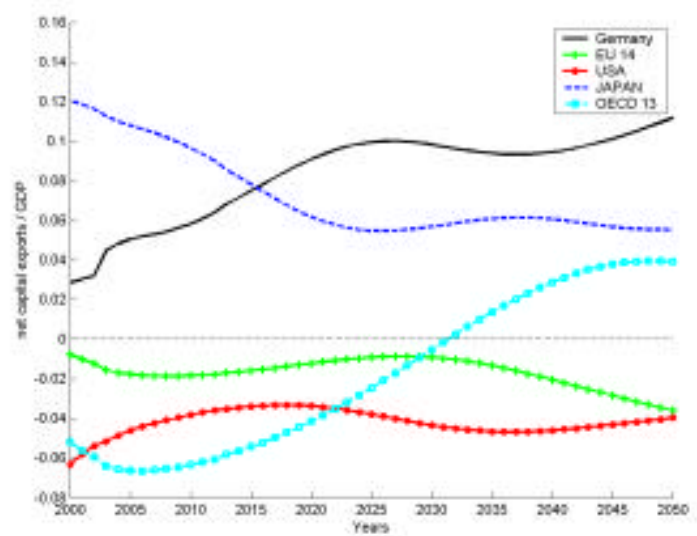

Notes: This figure shows projections of net capital exports of the respective region as a percentage of GDP under the assumption of perfect capital mobility within the OECD. Pension reform only in Germany. EU 14: all countries of the European Union except Germany. OECD 12: all OECD countries except for the countries of the European Union, Japan and the United States.

Source: Own calculations, based on demographic projections of the United Nations (2000) and age and gender-specific labor force participation rates by the OECD (2002).

Figure 22 als o shows how closely related the swings of capital exports are to the differential demographic processes. For example, the swings of Japanese capital exports are exactly opposite to the swings of German exports - just as the aggregate employment ratio. Also, while the OECD 13 is the youngest area, in relative terms, it is severely affected by aging. Accordingly, capital imports of this region decrease until the current account even becomes positive. Under a fundamental pension reform, 
German capital exports increase substantially and crowd out capital exports of all other world regions by about 0.8 percentage points in each country until 2050 .

For quantitative projections of international capital flows induced by population aging, the degree of capital mobility is crucial. This is an important research area for global aging. OLG models like those which produced figures 18-22 assume perfect capital mobility. This is a reasonable assumption within the euro zone. However, capital flows elsewhere are probably overestimated because many important factors that drive international capital flows like capital market frictions, capital market risk, home bias, and differential capital income taxation are ignored.

There has been no shortage of research on this issue since the famous puzzle of Feldstein and Horioka (1980). ${ }^{8}$ In their original contribution, Feldstein and Horioka have shown that national saving and investment rates are highly correlated in virtually all OECD countries. While the coefficient has fallen over time, it is still remarkably high. These findings have been interpreted as an indication that capital is imperfectly mobile. However, there is no lack of alternative explanations for the observed correlation (see e.g. Baxter and Crucini, 1993; Taylor, 1994; Obstfeld and Rogoff, 1996; Obstfeld and Rogoff, 2000).

Even if capital is fully mobile, this does not necessarily imply that households do actually diversify their portfolios optimally. There is a large empirical literature on 'home bias' in international portfolio choice (e.g., French and Poterba, 1991), and it is not yet fully understood why households do not optimally diversify their portfolios across countries. Portes and Rey (1999) suggest that information asymmetries across countries are a major source of home bias effects and that capital flows are affected by both geographic and informational proximity. Applied to pension reform policies, this literature suggests that households might be more willing to invest their retirement savings in 'similar' countries such as the EU or OECD countries than in, say, developing countries.

\subsection{Feedback effects through corporate governance}

\footnotetext{
${ }^{8}$ See Obstfeld and Rogoff (1996) and Coakley, Kulasi, and Smith (1998) for recent surveys.
} 
There are potentially important feedback effects of global aging on growth through capital market performance. Population aging is precipitating pension reform and with it the nature of capital markets in continental Europe. It is forcing the younger generation to provide more retirement income through own private saving. The markets for retirement savings are therefore growing in size, and active institutional investors are becoming more important as intermediaries. An important and still very controversial research question is to which extent population aging and pension reform, via a change in the savings behavior and portfolio composition of households, and via strengthening capital allocation and corporate governance through active institutional investors, are likely to have important and beneficial side effects on productivity and growth.

This topic is controversial, not the least because it is still open which form of corporate governance works best in the long run. It is an important topic because improved corporate governance might offset some of the negative macroeconomic implications of aging.

To see the strategic importance of this topic, it is helpful to start with three observations. France, Germany and Italy, the three largest economies in continental Europe, have large pay-as-you-go public pension systems which face severe problems due to population aging. At the very same time, these countries have thin capital markets. They are thin in the sense that only few households own and control productive capital (either directly or via investment and pension funds). French, German and Italian savers hold a considerable smaller share of stocks than households in the Netherlands, the United Kingdom and the United States. As a result, stock market capitalization is low in these three countries, and institutional investors such as pension funds play only a minor role in household saving, see table 1 . 
Table 1: Capital markets in countries with pay-as-you-go and funded pensions sys tems

\begin{tabular}{|c|c|c|c|c|c|c|c|}
\hline & \multirow[b]{2}{*}{ Year } & \multicolumn{3}{|c|}{ Pay-as-you-go systems } & \multicolumn{3}{|c|}{ Partially funded systems } \\
\hline & & France & Germany & Italy & Netherlands & UK & US \\
\hline \multirow{3}{*}{$\begin{array}{l}\text { Stock market capitalization } \\
(\% \text { of GDP })^{\mathrm{a}}\end{array}$} & 1995 & 32.6 & 23.9 & 19.3 & 72.1 & 121.6 & 95.2 \\
\hline & 1998 & 68.1 & 50.9 & 47.5 & 153.5 & 168.2 & 144.9 \\
\hline & 2000 & 111.8 & 67.6 & 72.3 & 174.3 & 183.8 & 153.3 \\
\hline \multirow{2}{*}{$\begin{array}{l}\text { Assets held by institutional } \\
\text { inve stors ( } \% \text { of GDP) }\end{array}$} & 1995 & 77.7 & 45.3 & 32.0 & 154.5 & 164.0 & 151.9 \\
\hline & 1998 & 107.3 & 66.1 & 79.6 & 193.2 & 203.6 & 192 \\
\hline $\begin{array}{l}\text { Assets held by pension funds } \\
\text { (\% of total assets of institu- }^{\text {o }} \\
\text { tional investors) }\end{array}$ & 1998 & . & 5 & 5 & 58 & 38 & 37 \\
\hline \multirow{2}{*}{$\begin{array}{l}\text { Assets held by pension funds } \\
\text { (billion USD) }{ }^{a}\end{array}$} & 1995 & . & 65.3 & 39.0 & 352.1 & 759.7 & $4,259.5$ \\
\hline & 1998 & . & 69.5 & 37.4 & 323.0 & $1,136.5$ & $7,161.6$ \\
\hline \multirow{2}{*}{$\begin{array}{l}\text { Pension fund investment } \\
(\% \text { of household wealth })^{d}\end{array}$} & 1995 & 1.8 & 5.6 & 0.8 & 35.5 & 22.3 & 23.4 \\
\hline & 2000 & 1.5 & 5.2 & 1.2 & 37.7 & 22.1 & 23.8 \\
\hline
\end{tabular}

Sources: a) Deutsches Aktieninstitut (2002); b) OECD (2001); c) OECD (2000); d) Babeau and Sbano (2003).

Second, France, Germany and Italy have, in comparison to the United States, poor capital performance as measured by aggregate capital productivity and various aggregate rates of return. While international comparisons of these statistics are not straightforward, the existing evidence summarized in table 2 yields a clear picture backed up by microeconomic evidence. Firms in France, Germany and Italy have substantially lower capital productivity and return on investment than U.S. companies achieve. Relative to the United States, financial underperformance is also correlated with bwer levels of total factor productivity. Many authors claim that an important cause for this underperformance is weak corporate governance (see, e.g., Wenger and Kaserer, 1998; Börsch-Supan, 1998; Mueller and Yurtoglu, 2000). 
Table 2: Capital performance relative to the United States

\begin{tabular}{lccc}
\hline & France & Germany & Italy \\
\hline Aggregate return on investment $^{\mathrm{a}}$ & 77 & 61 & 50 \\
Mean return on investment (firm sample) $^{\mathrm{b}}$ & 73 & 72 & 57 \\
Market sector capital productivity $^{\mathrm{c}}$ & 72 & 67 &. \\
Total factor productivity $^{\mathrm{d}}$ & 82 & 81 & 84 \\
\hline
\end{tabular}

Note: All figures are expressed as a percentage of the corresponding U.S. value.

Sources: a) Mueller and Yurtoglu (2000), Table 2. b) ditto, Table 4. c) Börsch-Supan (1998), Table 3.

d) Hall and Jones (1996), Table 9.

The relationships between these three observations (large PAYG systems, thin capital markets, and low capital productivity) are not well understood. A clear line of argument can be developed along the following two steps. First, population aging will change households' saving behavior because the internal rate of return generated by the pay-as-you-go pension systems will decrease, making own savings as a vehicle for retirement income both more necessary and attractive. In many countries, such as France, Italy, and Germany, population aging makes fundamental reform of public pension systems a top priority, strengthening own savings for retirement. Even if no additional savings were created in the aggregate, a larger share of savings will be devoted to retirement and flow through traded shares and bonds, intermediated by institur tional investors.

Second, the resulting larger share of intermediated capital will create thick-market extemalities and therefore increase productivity and growth. We are not the first to argue that the development of financial markets is an important factor in explaining the sources of productivity and economic growth, but the link to pension systems and pension reform is much less developed. ${ }^{9}$ In addition, there is some preliminary microeconomic evidence based on newly assembled firm data in Germany and Great Britain which shows that actively managed investment by institutional investors enhances corporate governance and through this

\footnotetext{
${ }^{9}$ See Levine (1997) for an extensive review of this literature. Köke (2002) reviews the peculiarities of a bank-based system such as in Germany. Börsch-Supan, Köke and Winter (2004) provide a literature survey tailored to the link between pension reform and capital market performance.
} 
channel increases productivity and growth (Köke and Rennerod, 2003; Börsch-Supan, Köke and Winter, 2004).

Research on these complex issues has not yet come far and enthusiasm for capital market related research has declined. The stock market crisis after the bubble burst and the ENRON scandal have cast grave doubts on capital market performance everywhere, including the United States. Moreover, evidence on firm performance in fundamentally different institutional settings is scarce, and establishing causality to explain observed differences is difficult. Nonetheless, capital markets will become ever more important as our populations age since capital has to substitute for increasingly scarce labor. Moreover, differential capital performance has important implications for global capital movements and the ability to cope with global aging.

\section{Summary and Conclusions}

Global aging will affect labor, product and capital markets in fundamental ways which will change the growth path of GDP and the wealth of nations. We understand the basic mechanisms behind these changes, are able to trace some of the complex feedback effects in general equilibrium, and have some rough ideas of the magnitudes involved. There is, however, as this paper has shown, still ample room to improve our current knowledge about feedback effects and to generate more precise qua ntifications.

Public policy can influence these labor, product and capital market changes essentially only on a microeconomic level - most directly by adapting the labor market to a situation in which labor is becoming increasingly scarce which slows down the economy. The main policy tools in order to utilize labor reserves are retirement and education policies.

Capital markets can diversify the risks generated by labor scarcity. They are therefore strategic markets in a globally aging world. The supply of capital is directly influenced by pension policies that foster savings. However, we do not fully understand the interactions between pension policy and economic growth. Policies such as prefunding and privatization appear to have significant side effects on the growth rate which are particularly welcome in times of global aging. 
The international transmission mechanisms that generate the helpful effects of diversification do not work smoothly. Understanding the frictions to the free flow of capital, the sources of instability in global financial markets, and the kind of policies that are appropriate to reduce frictions and instability, is an important and highly policy relevant research area for global aging. 


\section{REFERENCES}

Abel, Andrew B. (2001): Will Bequests Attenuate the Predicted Meltdown in Stock Prices when Baby Boomers Retire? Review of Economics and Statistics, 83(4), 589-595.

Alessie, R., and A. Kapteyn (2001): Household savings in the Netherlands. Research in Economics, $55,61-82$.

Altig, D., A.J. Auerbach, L.J. Kotlikoff, K.A. Smetters, and J. Walliser (2001): Simulating fundamental tax reform in the United States. American Economic Review, 91, 574-595.

Ando, A. and F. Modigliani (1963): The 'life-cycle' hypothesis of saving: Aggregate implications and tests. American Economic Review, 89(3), 605-618.

Attanasio, O.P. and G.L. Violante (2000): The demographic transition in closed and open economy: A tale of two regions. Working Paper 412, Research Department, Inter-American Development Bank, Washington, D.C.

Auerbach, A. J. and L. J. Kotlikoff (1987): Dynamic Fiscal Policy. Cambridge, MA: Cambridge University Press.

Babeau, A. and T. Sbano (2003): Household wealth in the national accounts of Europe, the United States and Japan. Working Paper 2003/2, Statistics Directorate, OECD, Paris.

Barth et al (1993): "Corporations and the Aging Workforce." Building the Competitive Workforce: Investing in Human Capital for Corporate Success, ed. Philip H. Mirvis: John Wiley \& Sons.

Baxter, M. and M. Crucini (1993): Explaining saving-investment correlations. American Economic Review, 83 (3), 416-436.

Bloom, D.E. and J.G. Williamson (1998): Demographic transitions and economic miracles in emerging Asia. World Bank Economic Review, 12(3), 419-455.

Bodie, Zvi, Robert C. Merton, and William F. Samuelson (1992): "Labor Supply Flexibility and Portfolio Choice in a Life-Cycle Model,”Journal of Economic Dynamics and Control, 16, 427-449.

Boeri, T., A. Börsch-Supan, and G. Tabellini (2001): Would you like to shrink the welfare state? The opinion ofEuropean citizens. Economic Policy, 32, 7-50.

Börsch-Supan, A. (1992): Saving and consumption patterns of the elderly: the German case. Journal of Population Economics, 5, 289-303. 
Börsch-Supan, A. (1996): The impact of population aging on savings, investment and growth in the OECD area. In: Future Global Capital Shortages: Real Threat or Pure Fiction? Paris: OECD, 103-141.

Börsch-Supan, A. (1998): Capital productivity and the nature of competition. Brookings Papers on Economic Activity - Microeconomics, 205-248.

Börsch-Supan, A. (2000), Incentive Effects of Social Security on Labor Force Participation: Evidence in Germany and Across Europe, Journal of Public Economics 78, 25-49.

Börsch-Supan, A. (2001): International comparison of household savings behavior: A study of life-cycle savings in seven countries. Research in Economics, 55, 1-14.

Börsch-Supan, A. (ed.) (2003a): Life-Cycle Savings and Public Policy, New York: Academic Press.

Börsch-Supan, A. (2003b): Labor Market Effects of Population Aging, Review of Labour Economics and Industrial Relations, Vol. 17, 5-44.

Börsch-Supan, A., I. Düzgün and M. Weiss (2004): Alter und Produktivität: Arbeitsgruppenbasierte Schätzungen in zwei ausgewählten Industriestandorten, Mannheim Research Institute for the Economics of Aging, Mannheim, Germany.

Börsch-Supan, A., J. Köke and J. Winter (2004): Pension Reform, Savings Behavior and Capital Market Performance, Mannheim Research Institute for the Economics of Aging, Mannheim, Germany.

Börsch-Supan, A., A. Ludwig and M. Sommer (2003), Demographie und Kapitalmärkte. Köln, Deutsches Institut für Altersvorsorge.

Börsch-Supan, A., A. Ludwig, and J. Winter (2002): Aging and international capital flows. In: A. Auerbach and H. Hermann (eds.), Aging, Financial Markets and Monetary Policy. Heidelberg: Springer, 55-83.

Börsch-Supan, A., A. Ludwig, and J. Winter (2004): Aging, pension reform, and capital flows. MEADiscussion Paper, University of Mannheim.

Börsch-Supan, A., A. Reil-Held und R. Schnabel (2003): Household Saving in Germany, In: BörschSupan (Ed.), Life Cycle Savings and Public Policy, Elsevier Science, 57-99.

Börsch-Supan, A., A. Reil-Held, R. Rodepeter, R. Schnabel, and J. Winter (2001): The German saving puzzle. Research in Economics, 55, 15-38. 
Börsch-Supan, A., and R. Schnabel (1998), Social Security and Declining Labor Force Particip ation in Germany, American Economic Review 88.2, 173-178.

Börsch-Supan, A., F. Heiss, A. Ludwig, and J. Winter (2003): Pension reform, capital markets, and the rate of return. German Economic Review, 4:2, 151-181.

Bosworth, B., R. Bryant and G. Burtless (2004): The Impact of Aging on Financial Markets and the Economy: A Survey, Mimeo, The Brookings Institution, Washington, DC.

Brooks, Robin (2002): Asset-Market Effects of the Baby-Boom and Social-Security Reform, American Economic Review, 92 (2), 402-406.

Brooks, Robin (2003): The Equity Premium and the Baby Boom, Mimeo, Washington: IMF.

Brugiavini, A. and M. Padula (2001): Too much for retirement? Saving in Italy. Research in Economics, 55, 39-60.

Bryant, R.C., H. Faruqee and D. Velculescu (2001): Youth dependency and demographic change: Implications for the global economy. Mimeo, Brookings Institution, Washington, D.C.

Buchheim, C. (1998), Industrielle Revolutionen, dtv: Munich.

Buiter, W.H. (1981): Time preference and international lending and borrowing in an overlappinggenerations model. Journal of Political Economy, 89(4), 769-797.

Campbell, John Y., and Luis M. Viceira (2002): Strategic Asset Allocation - Portfolio Choice for LongTerm Investors, New York: Oxford University Press.

Cigno, A. (1995), Public pensions with endogenous fertility, Journal of Public Economics 57, 169173, 1995.

Coakley, J., F. Kulasi, and R. Smith (1998): The Feldstein-Horioka puzzle and capital mobility: A review. International Journal of Finance and Economics, 3(2), 169-188

Constantinides, George M., John B. Donaldson, and Rajnish Mehra (2002): Quarterly Journal of Economics, 269-296.

Cutler, D.M., J.M. Poterba, L.M. Sheiner, and L.H. Summers (1990): An aging society: Opportunity or challenge? Brookings Papers on Economic Activity, No. 1, 1-73.

De Nardi, M., S. Imrohoroglu, and T.J. Sargent (1999): Projected U.S. demographics and social security. Review of Economic Dynamics, 2, 575-615. 
Deardorff, A.V. (1985) „Trade and Capital Mobility in a World of Diverging Populations“ In: D.G. Johnson and R.D. Lee (eds.), Population Growth and Economic Development: Issues and Evidence. Madison, WI: University of Wisconsin Press.

Deaton, Angus S., and Christina H. Paxson (1994): “Saving, Growth and Ageing in Taiwan,” in: Studies in the Economics of Ageing, ed. by D. Wise, 331-357. Chicago: Chicago University Press.

Deutsches Aktieninstitut (2002): DIA Factbook. Frankfurt am Main: Deutsches Aktieninstitut.

Diamond, P.A. (1965): National debt in a neoclassical growth model. American Economic Review, $55,1126-1150$.

Eichengreen, B. and Fifer, M. (2002): The Implications of Aging for the Balance of Payments between North and South, in: Siebert, H. (ed): Economic Policy for Aging Societies, Springer, Heider berg

Eschtruth, A.D., and J. Gemus (2002): Are Older Workers Responding to the Bear Market? Just the Facts, Issue September 2002, Nr. 5, Center for Research on Retirement at Boston College.

Fall, M., C. Loisy, and G. Talon (2001): An empirical analysis of household savings in France 1984 1998. Research in Economics, 55, 155-172.

Fehr, H. (2000): Pension reform during the demographic transition. Scandinavian Journal of Economics, 102(3), 419-443.

Feldstein, M. and C. Horioka (1980): Domestic saving and international capital flows. Economic Journal, 90, 314-329.

Feroli, M (2002): Capital flows among the G-7 Nations: a demographic perspective. Working Paper, New York University.

French, K.R. and J.M. Poterba (1991): Investor diversification and international equity markets. American Economic Review, Papers and Proceedings, 81(2), 222-226.

Gruber, J., and D. Wise (1999), Social Security and Retirement Around the World. Chicago, London: University of Chicago Press.

Guiso, L., T. Jappelli, and M. Haliassos (2002): Household Portfolios. Cambridge, Mass.: MIT-Press.

Hall, R. E. and C. I. Jones (1996): The productivity of nations. Working Paper No. 5812, National Bureau of Economic Research, Cambridge, MA. 
Hamermesh, D.S. (2001), Older Workers in the Coming Labor "Shortage": Implications of Labor Demand. Paper prepared for the Roundtable on the Demand for Older Workers, The Brookings Institution, March 2001.

Hank. K., and M. Kreyenfeld (2003): A Multilevel Analysis of Child Care and Women's Fertility Deci sions in Western Germany, Journal of Marriage and Family, 65 (3), 2003, pp.584-596.

Higgins, M. (1998): Demography, national savings, and international capital flows. International Economic Review, 39, 343-369.

Hirte, G. (2002): Welfare and macroeconomic effects of the German pension acts of 1992 and 1999: A dynamic CGE study. German Economic Review , 3, 81-106.

Hutchens, R.M. (2001), Employer Surveys, Employer Policies, and Future Demand for Older Workers. Paper prepared for the Roundtable on the Demand for Older Workers, The Brookings Institution, March 2001.

INGENUE (2001): Macroeconomic consequences of pension reforms in Europe: An investigation with the INGENUE world model. Working Paper No. 2001-16, CEPREMAP, Paris.

Jappelli, T. and F. Modigliani (1998), The age-saving profile and the life-cycle hypothesis, CSEF Working Paper No. 4, University of Salerno.

Köke, J. (2002): Corporate governance in Germany: An empirical investigation. Heidelberg: Physica.

Köke, J. and L. Renneboog (2002): Does good corporate governance lead to stronger productivity growth? Evidence from market-oriented and blockholder-based governance regimes. Discussion Paper No. 2002-89, CentER, Tilburg University.

Kotlikoff, L. and D. Wise (1989), Employee Retirement and a Firm's Pension Plan, in D.A. Wise, ed., The Economics of Aging, Chicago: University of Chicago Press, 279-334.

Kotlikoff, L.J. (2000): The A-K OLG model: Its past, present, and future. In: Harrison, G. (ed.): Using dynamic general equilibrium models for policy analysis, 13-52.

Kotlikoff, L.J., K. Smetters, and J. Walliser (1999): Privatizing social security in the United States: Comparing the options. Review of Economic Dynamics, 2, 532-574.

Lee, R. 1993, "Modelling and forecasting the time series of US fertility: Age patterns, range and ultimate level," In: International Journal of Forecasting 9, 187-202. 
Lee, R. 1998, “Probabilistic Approaches to Population Forecasting”, In: Population and Development Review 24, Issue Supplement: Frontiers of Population Forecasting, 156 - 190.

Lee R. und Tuljapurkar, S. 1994, "Stochastic population projections for the United States: Beyond high, medium and low," In: Journal of the American Statistical Association 89 (428), 1175-1189.

Levine, R. (1997): Financial development and economic growth: Views and agenda. Journal of Economic Literature, 35, 688-726.

Lührmann, M. (2002): Demographic change, foresight, and international capital flows. Unpublished manuscript, MEA, University of Mannheim.

Mehra, R. and Prescott, E. (1985): The Equity Premium: A Puzzle, Journal of Monetary Economics, 15, S. $145-161$

Miles, D. (1999): Modeling the impact of demographic change upon the economy. Economic Journal, 109, 1-36.

Miles, D. and A. Iben (2000): The reform of pension systems: Winners and losers across generations in the United Kingdom and Germany. Economica, 67, 203-228.

Modigliani, F. and R. Brumberg (1954): Utility analysis and the consumption function: An interpretation of cross-section data. In K.K. Kurihara (ed.): Post-Keynesian Economics. New Brunswick: Rutgers University Press, 388-436.

Mueller, D. C. and B. B. Yurtoglu (2000): Country legal environments and corporate investment performance. German Economic Review, 1, 187-220.

Obstfeld, M. and K. Rogoff (1996): Foundations of international macroeconomics, MIT Press, Cambridge, MA.

Obstfeld, M. and K. Rogoff (2000): The six major puzzles in international macroeconomics: Is there a common cause? NBER Macroeconomics Annual, 15, 339-390.

Organization for Economic Cooperation and Development (2000): Institutional Investors - Statistical Yearbook. Paris: OECD.

Organization for Economic Cooperation and Development (2001): Financial Market Trends, No. 80. Paris: OECD.

Organization for Economic Cooperation and Development (2002): Labor force statistics. Paris: OECD. 
Pemberton, J. (1999): Social security: National policies with international implications. Economic Journal, 109, 492-508.

Pemberton, J. (2000): National and international privatization of pensions. European Economic Review, 44, 1873-1896.

Portes, R. and H. Rey (1999): The determinants of cross-border equity flows. Working Paper No. 7336, National Bureau of Economic Research, Washington, D.C.

Poterba, J.M. (2001): Demographic structure and assets returns. Review of Economics and Statistics, $83(4), 565-584$.

Reisen, H. (2000): Pensions, Savings and Capital Flows: From Aging to Emerging Markets. Chet tenham, UK: Edward Elgar.

Samuelson, P.A. (1958): An exact consumption-loan model of interest with or without social contrivance of money. Journal of Political Economy, 66, 467-482.

Sinn, H.-W. (1997): The Value of Children and Immigrants in a Pay-as-you-go Pension System: A Proposal for a Partial Transition to a Funded System, CESifo Working Paper 141, Munich, Germany.

Skirbekk, V. (2004a): Completing Education and the Timing of Births and Marriage: Findings from a Birth-Month Experiment in Sweden, Working paper of the Max Planck Institute for Demographic Research, Rostock, Germany.

Skirbekk, V. (2004b): Population Aging and Productivity, Working paper of the Max Planck Institute for Demographic Research, Rostock, Germany.

Taylor, A.M. (1994): Domestic saving and international capital flows reconsidered. Working Paper No. 4892, National Bureau of Economic Research, Washington, D.C.

United Nations Population Division (2001): World Population Prospects: The 2000 Revision. New York: United Nations.

Wenger, E. and C. Kaserer (1998): The German system of corporate governance - A model which should not be imitated. In: S. Black and M. Moersch (eds.), Competition and Convergence in Financial Markets: The German and Anglo-American Models. Amsterdam: Elsevier, 41-78. 


\begin{tabular}{lll}
\hline \hline Nr. & Author & Title \\
\hline
\end{tabular}

07-19 Jürgen Eichberger

David Kelsey

Burkhard Schipper

07-18 Jürgen Eichberger

Willy Spanjers

07-17 Patrick A. Müller

Jana Janßen

Dominique Jarzina

07-16 Patrick A. Müller

Dagmar Stahlberg

07-15 Axel Börsch-Supan

Anette Reil-Held

Daniel Schunk

07-14 Axel Börsch-Supan

Dirk Krüger

Alexander Ludwig

07-13 Melanie Lührmann

07-12 Axel Börsch-Supan

Anette Reil-Held

Christina Wilke

07-11 Alexander Ludwig

Dirk Krüger

07-10 Daniel Schunk

07-09 Axel Börsch-Supan Anette Reil-Held

Christina Wilke
Ambiguity and Social Interaction

Liquidity and Ambiguity: Banks or Asset Markets?

Applicantsí reactions to selection procedures $\tilde{n}$ Prediction uncertainty as a moderator of the relationship between procedural fairness and organizational attractiveness

The Role of Surprise in Hindsight Bias ñ A Metacognitive Model of Reduced and Reversed Hindsight Bias

Das Sparverhalten deutscher Haushalte: Erste Erfahrungen mit der Riester-Rente

Demographic Change, Relative Factor Prices, International Capital Flows, and their Differential Effects on the Welfare of Generations

Consumer Expenditures and Home Production at Retirement: New Evidence from Germany

Zur Sozialversicherungsfreiheit der

Entgeltumwandlung

On the Consequences of Demographic Change for Rates of Returns to Capital, and the Distribution of Wealth and Welfare

What Determines the Saving Behavior of German Households? An Examination of Saving Motives and Saving Decisions

How an Unfunded Pension System looks like

Defined Benefits but works like Defined

Contributions: The German Pension Reform 